\title{
Os estilos de liderança na gestão hoteleira: um estudo em hotéis da orla de João Pessoa (PB)
}

\section{The styles of leadership in hotel management: a study in hotels on the border of João Pessoa (PB)}

\author{
THALES BATISTA DE LIMA* \\ SABRINA LIMA GOMES**
}

\section{RESUMO}

Liderança é um tema discutido com frequência nos dias atuais devido ao cenário competitivo em que estão inseridas as organizações, principalmente aquelas que pertencem ao setor de serviços como os empreendimentos hoteleiros. Assim, o trabalho objetiva analisar a influência dos estilos de liderança no funcionamento da gestão nos hotéis da orla de João Pessoa (PB). O estudo utilizou a abordagem quantitativa e se caracteriza pelo método dedutivo e descritivo. Foi desenvolvido um questionário para obter as informações acerca da temática dos estilos de liderança, no qual houve a participação de 12 gestores. Para a análise dos dados, foi utilizada a análise estatística descritiva, cujos resultados explicitaram que os estilos de liderança utilizados pelos gestores influenciam o funcionamento dos hotéis pesquisados, e foram identificados três (autocrático, liberal e democrático) simultaneamente. Os maiores desafios enfrentados por eles são manter a equipe sempre motivada, atender às necessidades de cada um e respeitar as diferenças. Logo, concluiu-se que a influência dos estilos de liderança no funcionamento da gestão nos hotéis da orla de João Pessoa (PB) pode refletir na excelência do serviço prestado e no ambiente de trabalho mais agradável e alinhado aos objetivos do hotel.

Palavras-chave: Estilos de liderança; gestores; hotelaria.

\footnotetext{
* Universidade Federal da Paraíba. Professor Adjunto do DCSA/CCAE/UFPB. thalesbatista@gmail.com .

** Universidade Federal da Paraíba. Bacharel em Hotelaria. sassalimagomes@gmail.com .
} 


\section{Abstract}

Leadership is a topic frequently discussed today, due to the competitive landscape in which organizations are inserted, especially those belonging to the service sector, such as hotel ventures. Thus, the objective of this work is to analyze the influence of leadership styles on the management of hotels in the João Pessoa - PB border. The study used the quantitative approach and characterized by the deductive and descriptive method. A questionnaire was developed to obtain information about the topic of leadership styles, in which there were the participation of 12 managers. For the analysis of the data, the descriptive statistical analysis was used, whose results explained that the leadership styles used by the managers influence the operation of the researched hotels, where they usually use the three leadership styles (autocratic, liberal and democratic) simultaneously. The biggest challenges they face are keeping the team motivated, meeting each other's needs and respecting differences. Therefore, it concluded that the influence of leadership styles in the management of João Pessoa - PB hotels could reflect the excellence of the service provided and the work environment that is more pleasant and aligned with the hotel's objectives.

Keywords: Leadership styles; management; hospitality.

\section{INTRODUÇÃo}

A liderança, de acordo com Chiavenato (2003, p. 122), “é necessária em todos os tipos de organização humana, seja nas empresas, seja em cada um de seus departamentos". Isto é, a presença do líder dentro das instituições é fundamental para que elas consigam atingir seus objetivos, principalmente na contemporaneidade, levando-se em consideração as constantes mudanças que vêm acontecendo no cenário em que estão inseridas.

A princípio, chamavam-se líderes aquelas pessoas que apresentavam características diferentes das demais; acreditava-se que elas já nasciam assim. No entanto, os estudos sobre liderança tomaram uma forma mais organizada a partir da Revolução Industrial: para Barreto e Tanure (2011), eles buscavam determinar as características e os atributos que caracterizavam a figura do líder. Esses estudos foram chamados de Teoria dos Traços e predominaram até a metade do século XX. 
Posteriormente, surgiram as teorias comportamentais que afirmavam, segundo Lima e Carvalho Neto (2011), que o líder não nasce com as características necessárias, mas pode aprender sobre elas e adquiri-las por meio de técnicas de desenvolvimento pessoal, ajustando comportamentos para a formação de líderes. Dentre essas teorias, as mais importantes são a Teoria X e Y de McGregor (1966) e a desenvolvida por Blake e Mouton (1980) chamada de Grid Gerencial.

Ainda dentro dessas teorias comportamentais, surgiram estudos, nas décadas de 1950 e 1960, que investigaram os estilos de liderança utilizados pelos líderes, tendo como base seu comportamento mediante os seus liderados. Chiavenato (2003) afirma que esses estilos podem ser divididos em autocrático, democrático e liberal.

Os estudos sobre a liderança avançaram, e surgiu uma nova teoria com um enfoque situacional, ou seja, o ambiente em que o líder e seu grupo estão inseridos interfere no comportamento e no estilo de liderança a ser adotado. A partir da década de 1980, novos estudos surgiram; de acordo com Vieira (2014, p. 7), “enfatizam não somente os líderes, a forma como as decisões são tomadas ou os liderados, mas o tipo de recompensa que os líderes oferecem a seus seguidores"; e a liderança foi dividida em transacional e transformacional. Entretanto, as abordagens mais modernas sobre o tema consideram, conforme Delfino, Silva e Rohde (2010), a existência de equipes com um líder formal, e outras com um líder informal que surge no interior do grupo, e é compartilhada.

Além disso, a tecnologia trouxe muitas mudanças na forma de gerenciar as empresas, segundo a qual, para Santos M. (2013, p. 13), "atualmente grande parte das empresas se utiliza de meios tecnológicos que contribuem para o bom desempenho das suas tarefas". Ou seja, proporciona mais agilidade na execução das atividades para atingir os objetivos propostos de modo que, por possuir habilidades e estar atento às mudanças, o líder consegue tanto administrar os recursos tecnológicos disponíveis dentro das empresas quanto motivar os funcionários. A tecnologia também pode trazer benefícios ao estilo de liderança adotado pelo líder, devido aos sistemas informatizados presentes nas organizações, facilitando a comunicação interna e o relacionamento com os clientes. 
Portanto, a liderança passa a exercer um papel fundamental nas instituições, especialmente a partir da Revolução Industrial; esta trouxe não apenas novas tecnologias para facilitar e melhorar o trabalho, mas também uma nova maneira de gerenciar a organização e estudos sobre as características, comportamento, estilo de liderar e recompensas utilizadas pelo líder. Essas tecnologias também modificaram a forma como organizações vendem e comercializam produtos e serviços, visto que a comunicação ficou mais rápida e os clientes passaram a ter mais acesso às informações.

Por isso, a figura do líder é importante em qualquer organização, principalmente em empreendimentos hoteleiros, cujo principal foco é a oferta de serviços de qualidade aos clientes. Para isso, é necessária uma equipe de funcionários qualificados, pois só ele consegue motivá-los mediante seu estilo de liderança e, juntos, conseguem alcançar as metas estabelecidas.

Sendo assim, este trabalho tem o intuito de analisar a influência dos estilos de liderança no funcionamento da gestão nos hotéis da orla de João Pessoa (PB).

\section{REFERENCIAL TEÓRICO}

Discorre-se sobre o tema e sua relação com o campo de estudo, ou seja, a liderança no setor hoteleiro.

\subsection{Evolução e conceituação de liderança}

A liderança é um tema que, desde o seu surgimento, tem gerado muitos estudos e pesquisas ao longo dos anos; entretanto, ainda é possível encontrar diferentes conceitos a seu respeito. No início, pensava-se que os líderes já nasciam com esses atributos e que suas características podiam ser ensinadas a outras pessoas e desenvolvidas por elas. Depois, surgiu a ideia de que as pessoas ou a tarefa que o líder desempenha na organização afetam o seu comportamento, e também que o líder pode adotar estilos diferentes de liderança.

A busca pela compreensão da temática, segundo Sant'Anna, Campos e Vaz (2010), vem desde os egípcios, e se refere ao primeiro registro escrito acerca do assunto em que a liderança é vista como algo transcendental ao ser humano e que o líder se distingue dos demais por apontar qualidades superiores. Esse pensamento 
pode ser atrelado a outras civilizações que marcaram a história da humanidade, pois por muito tempo aqueles que apresentavam características diferentes dos outros eram chamados de líderes e, para muitas pessoas, eles nasciam com o dom.

Com a chegada da Revolução Industrial, no século XVIII, os estudos sobre liderança tomaram uma forma mais sistemática, orientando-se para a "identificação de características e atributos de grandes personalidades, as quais deveriam servir de modelo e base para as ações de formação de novos líderes" (SANT'ANNA; CAMPOS; VAZ, 2010). De acordo com Barreto e Tanure (2011), esses estudos predominaram até a metade do século XX e foram chamados de teoria dos traços. Essa teoria, segundo Delfino, Silva e Rohde (2010), mantém seu foco na figura do líder, nas características físicas e de personalidade, visto que ele já nasceria com traços inatos e a liderança se desenvolveria naturalmente.

Diante da abordagem teórica que a teoria dos traços apresentava, Sant'Anna, Campos e Vaz (2010) comentam que estudos seguintes, inicialmente dirigidos por Kurt Lewin, se direcionaram à compreensão da dinâmica do comportamento dos líderes no grupo, analisando indivíduos nessa posição. A partir desse estudo, conhecendo os comportamentos deles, seria possível treinar as pessoas para se tornarem grandes líderes.

Para Robbins (2005), as teorias comportamentais mais abrangentes e reprodutivas resultaram de uma pesquisa iniciada no final de 1940 na Universidade Estadual de Ohio (EUA). Sant'Anna, Campos e Vaz (2010) afirmam que, entre os resultados encontrados, verificou-se que parte das atividades do líder se encontra ligada a coisas ou tarefas, e outra parte a pessoas, configurando-se duas predisposições ou dimensões distintas de liderança.

Outros estudos foram realizados pela Universidade de Michigan (EUA) no intuito de se compreenderem melhor os aspectos conceituais da temática a partir das práticas visualizadas nas organizações, por meio dos comportamentos de indivíduos que exerciam cargos de importância na gestão. Dessa forma, os estudiosos desta universidade norte-americana obtiveram resultados similares aos da Universidade de Ohio, cujo objetivo era conduzido na identificação 
das características comportamentais dos líderes que pudessem estar relacionadas com o desempenho eficaz.

Chegaram a duas dimensões do comportamento de liderança, denominadas de orientação para o funcionário e orientação para a produção (ROBBINS, 2005). As conclusões foram extremamente favoráveis ao comportamento dos líderes orientados para os funcionários, pois estavam ligadas a maior produtividade do grupo e mais satisfação com o trabalho. Nesse caso, tratava-se de uma liderança atrelada ao relacionamento interpessoal.

Seguindo ainda pela abordagem comportamental, na qual a liderança, de acordo com Lima e Carvalho Neto (2011), pode ser aprendida por meio de técnicas de desenvolvimento pessoal e, a partir disso, alterando e adequando comportamentos para formar líderes, Blake e Mouton (1980) propuseram um modelo chamado de Grid ou Grade Gerencial em que “os estilos de liderança são representados por cinco tipos de gerência em um diagrama que visa à medição da preocupação do líder em relação às pessoas e à produção" (SANTOS et al., 2011, p. 6). Ou seja, o líder conseguiria alterar seu comportamento e poderia usar duas formas de gestão: uma voltada para a produção, e outra, às relações sociais ou combinar as duas.

Entretanto, segundo Robbins (2005) o grid oferece apenas uma melhor maneira para a definição do estilo de liderança, sem divulgar qualquer nova informação que seja suficiente para esclarecer a questão; além disso, existia pouca evidência de que esse modelo era o mais eficaz para o desenvolvimento de lideranças.

Outras teorias também foram desenvolvidas, ligadas ao desenvolvimento de pessoal, por meio de aspectos motivacionais exercidas pelos indivíduos em postos de liderança na organização. Foi o caso da chamada Teoria X e Y de McGregor (1966), na qual, de acordo com Barreto e Tanure (2011), a teoria $X$ sugere que o estilo de administração é tradicional, inflexível em suas opiniões e controlador, e que considera o salário como única motivação para os funcionários. Já na teoria $Y$, a liderança tem a habilidade para liberar e expandir o potencial dos colaboradores e motivá-los por meio de medidas inovadoras e humanistas. Assim, Silva (2008) complementa: 
O resumo da teoria $X$ é a suposição de que o homem é, por natureza, indolente, evita o trabalho, não tem ambição, desgosta da responsabilidade e prefere ser dirigido. [...] O resumo da teoria Y encerra a suposição de que o indivíduo não é, por natureza, preguiçoso e não confiável. Essa visão propõe que as pessoas podem se autodirigir e ser criativas no trabalho, desde que adequadamente motivadas. (SILVA, 2008, p. 232-233)

Portanto, a teoria $X$ se refere ao controle dos funcionários de maneira autoritária, em que eles devem seguir as regras, e não há nenhum desenvolvimento de suas habilidades. Por outro lado, na teoria $\mathrm{Y}$ os colaboradores não só são motivados e estimulados pelos líderes a expressar suas ideias, mas também isso proporciona melhor ambiente de trabalho. Lacombe (2005) ressalta que ocorre com certa frequência o fenômeno da profecia autorrealizável, no qual as pessoas têm a tendência de se comportar de acordo com o que se espera delas. Logo, na maioria dos casos, a teoria Y propicia um comportamento mais saudável e mais adequado para a aquisição dos resultados desejados.

Ainda com enfoque na abordagem comportamental, surgiram pesquisas na década de 1950 e 1960 que buscavam estudar os estilos de liderança dos líderes com base no seu comportamento com os liderados. Latoski, Mello e Nogueira (2014) comentam que os três estilos de liderança podem ser divididos em autocrático, democrático e liberal (laissez-faire). No autocrático, o líder comanda a equipe impondo ordens; no democrático, considera as opiniões dos liderados; e no liberal, participa menos das decisões, permitindo maior liberdade da equipe.

Todavia, para Silva (2008, p. 241), “o sucesso do líder pode ser devido parcialmente a certos traços de personalidade ou a seu comportamento, mas também é determinado por quão bem aquelas abordagens atendem às necessidades dos subordinados e às características da situação". Ou seja, o ambiente no qual o líder está inserido, assim como os seus liderados, também interfere no seu estilo de liderança, e essa adaptação é relatada como uma abordagem contingencial. 
Com o avanço das teorias organizacionais, segundo as quais as instituições são vistas em perspectivas sistêmicas e contingenciais, surgem diferentes conceituações de liderança. Sendo assim, uma teoria no âmbito contingencial da liderança é a de House e Mitchell, a qual "propõe que os líderes influenciam os subordinados pela clarificação do que deve ser feito (o caminho) para obter recompensas que eles desejam (a meta)" (SILVA 2008, p. 245). Ou seja, os líderes ajudam melhor os subordinados, na forma de explicar o que eles devem ou deveriam fazer para obter as recompensas desejadas, adotando diferentes estilos de liderança.

"Sendo um enfoque contingencial ou situacional, o líder irá adequar seu comportamento, conforme aspectos da tarefa e dos colaboradores" (HOUSE; MITCHELL, 1974, apud SANT'ANNA; CAMPOS; VAZ, 2010, p. 5). Para o desenvolvimento da liderança essas teorias foram importantes, pois possibilitam vê-la de forma mais dinâmica, todavia seus resultados não foram comprovados.

Como já dito, as primeiras abordagens sobre liderança foram atreladas às características físicas e de personalidade dos líderes (a teoria dos traços). Entretanto, por terem sido uma abordagem mais teórica, surgiu outra, denominada comportamental e pela qual, conhecendo o comportamento dos líderes, seria possível treinar outras pessoas. Porém, também se percebeu que o local onde o líder está inserido assim como os seus liderados interferem no seu comportamento, e essa abordagem recebeu o nome de contingencial.

Assim, na década de 1980, emergiu uma nova linha de pensamento sobre a liderança, em que "o líder é identificado como articulador de uma visão que reflete os valores e a missão organizacional" (DELFINO; SILVA; ROHDE, 2010, p. 4). Giuliani e Oliva (2014) argumentam que Burns (1978) caracterizou a liderança como transacional e transformacional. A transacional, de acordo com Lima e Carvalho Neto (2011), se caracteriza por um processo de troca entre líderes e liderados, em que os líderes conseguem compreender os desejos dos liderados e se esforçam para realizá-los, mas em troca estes devem cumprir certas metas. Ou seja, os funcionários só ganham recompensas se realizarem o que foi estabelecido pelo líder. E essa troca pode ser de natureza econômica (salário), política (promoção, férias) ou psicológica (elogio, reconhecimento). 
Já na liderança transformacional, "o líder procura satisfazer as necessidades dos seus seguidores, tratando-os como pessoas únicas e singulares, cujos potenciais podem ser despertos e aproveitados" (BARRETO; TANURE 2011, p. 4). Ou seja, o líder tem maior aproximação com cada um dos seus liderados, proporcionando um ambiente organizacional harmonioso e um relacionamento de ajuda mútua entre eles. Bass (2008, apud GIULIANI; OLIVA, 2011) comenta que o líder transformacional consegue aumentar o nível de maturidade dos colaboradores e motivá-los sem utilizar o poder.

Portanto, na liderança transacional existe uma troca entre o líder e os liderados, pois os liderados só ganham alguma recompensa se atingir os objetivos propostos pelo líder. Já na transformacional prevalece o comprometimento do líder e dos liderados em se ajudarem para juntos conseguirem obter os resultados desejados.

Entretanto, a definição de líder evoluiu e as abordagens mais modernas "canalizam seus esforços para os estudos das equipes multifuncionais - que possuem líder formal - e as equipes autolideradas - onde a figura do líder não é percebida como um posto de destaque" (YUKL, 1998, apud DELFINO; SILVA; ROHDE, 2010, p. 5). Ou seja, existem as equipes que possuem um líder determinado e aquelas em que a liderança está espalhada no grupo, que estimula as pessoas a se liderarem.

Ainda sobre essas novas abordagens acerca da liderança, podem ser citadas outras duas: a criativa e a autêntica. A liderança criativa, de acordo com Roldan, Cabral e Pessoa (2012), foi definida por Rickards e Moger (2000) como o procedimento de mudança da atuação criativa da equipe de inaceitável para aceitável, e de aceitável para superior, desencadeado pela inserção de "estruturas benignas" que beneficiem a cooperação e mutualidade. Já na autêntica, o líder, segundo Eboli, Cavazotte e Lucena (2012, p. 3), "agiria de acordo com seus profundos valores e convicções para construir credibilidade e ganhar o respeito e confiança dos seus subordinados".

Logo se percebe que cada uma das abordagens influenciou na criação da outra, mas a figura do líder sempre permaneceu importante, seja na sociedade, seja no grupo em que ele está inserido dentro da organização. Entretanto, um dos fatores de grande relevância é a respeito do estilo de liderança que o líder deve adotar para que ao mesmo tempo saiba corretamente motivar seus liderados e também atingir os objetivos da organização. 


\subsection{Estilos de liderança}

Como foi dito anteriormente, o líder exerce um papel importante tanto na sociedade quanto no grupo em que está inserido na organização. No entanto, para que obtenha sucesso, ele precisa definir um estilo de liderança, ou seja, um modo adequado de motivar os liderados. Nesse sentido, "as teorias sobre estilos de liderança são teorias que estudam a liderança em termos de estilos de comportamento do líder em relação aos seus subordinados" (CHIAVENATO 2003, p. 124). Em outras palavras, refere-se àquilo que o líder faz, à forma como lidera a equipe, de que maneira se comporta e como isso afeta o grupo. De acordo com esse mesmo autor, a teoria mais conhecida diz respeito a três estilos de liderança:

I. Liderança autocrática: o líder concentra as decisões para ele e impõe suas ordens ao grupo. O comportamento entre os liderados é de frustação, visto que prevalece um clima tenso e agressivo. Além disso, não há iniciativa para que eles sejam espontâneos e construam amizades entre si. Eles realizam suas tarefas sem nenhuma satisfação, e o trabalho só é realizado com a presença física do líder.

II. Liderança liberal (laissez-faire): o líder concede o poder das decisões totalmente aos liderados, fazendo com que eles fiquem à vontade e sem qualquer controle. Além disso, o grupo não executa com qualidade suas tarefas que são desenvolvidas ao acaso, mesmo produzindo de forma intensa. Percebe-se um forte individualismo e pouco respeito ao líder.

III. Liderança democrática: o líder conduz e posiciona o grupo e estimula a participação democrática das pessoas. Apresenta formação de grupos de amizade, e o relacionamento entre o líder e os liderados é de maneira educada, honesta e espontânea. Além disso, o grupo trabalha num ritmo suave e seguro, com responsabilidade e comprometimento pessoal gerando um clima de satisfação no ambiente de trabalho.

Latoski, Mello e Nogueira (2014) comentam que os líderes cujo propósito é a manutenção do próprio poder ou de um grupo utilizam o estilo da liderança autocrática, visto que o líder é quem determina as regras e não permite que os subordinados opinem 
sobre elas. Na liderança liberal, o líder permite que os funcionários tenham autonomia na tomada de decisões: ele só participa quando é solicitado. Já com relação à liderança democrática, o foco do líder consiste em desenvolver as habilidades e capacidades dos liderados, proporcionando maior e saudável interação entre eles.

No Quadro 1 é possível observar as características desses três estilos de liderança de maneira mais clara.

Quadro 1: Os três estilos de liderança

\begin{tabular}{|l|l|l|}
\hline Autocrática & Democrática & $\begin{array}{l}\text { Liberal (laissez-fai- } \\
\text { re) }\end{array}$ \\
\hline $\begin{array}{l}\text { O líder fixa as dire- } \\
\text { trizes, sem qualquer } \\
\text { participação do grupo }\end{array}$ & $\begin{array}{l}\text { As diretrizes são debati- } \\
\text { das e decididas pelo gru- } \\
\text { po, estimulado e assistido } \\
\text { pelo líder }\end{array}$ & $\begin{array}{l}\text { Há liberdade total } \\
\text { para as decisões gru- } \\
\text { pais ou individuais e } \\
\text { mínima participação } \\
\text { do líder }\end{array}$ \\
\hline $\begin{array}{l}\text { O líder determina as } \\
\text { providências para a } \\
\text { execução das tarefas, } \\
\text { cada uma por vez, à } \\
\text { medida que se tornam } \\
\text { necessárias e de modo } \\
\text { imprevisível para o } \\
\text { grupo }\end{array}$ & $\begin{array}{l}\text { O grupo esboça as pro- } \\
\text { vidências para atingir } \\
\text { o alvo e pede aconse- } \\
\text { lhamento do líder, que } \\
\text { sugere alternativas para o } \\
\text { grupo escolher; as tarefas } \\
\text { ganham novas perspecti- } \\
\text { vas com os debates }\end{array}$ & $\begin{array}{l}\text { A participação do } \\
\text { líder é limitada, } \\
\text { apresentando apenas } \\
\text { materiais variados } \\
\text { ao grupo, esclare- } \\
\text { cendo que pode } \\
\text { fornecer informações } \\
\text { desde que as peçam }\end{array}$ \\
\hline $\begin{array}{l}\text { O líder determina a ta- } \\
\text { refa que cada um deve } \\
\text { executar e o seu com- } \\
\text { panheiro de trabalho }\end{array}$ & $\begin{array}{l}\text { A divisão das tarefas fica } \\
\text { a critério do grupo e cada } \\
\text { membro tem liberdade de } \\
\text { escolher seus companhei- } \\
\text { ros de trabalho }\end{array}$ & $\begin{array}{l}\text { A divisão das tarefas } \\
\text { e a escolha dos cole- } \\
\text { gas ficam totalmente } \\
\text { a cargo do grupo; } \\
\text { absoluta falta de } \\
\text { participação do líder }\end{array}$ \\
\hline $\begin{array}{l}\text { O líder é dominador e } \\
\text { "pessoal" nos elogios e } \\
\text { nas críticas ao trabalho } \\
\text { de cada membro }\end{array}$ & $\begin{array}{l}\text { O líder procura ser um } \\
\text { membro normal do gru- } \\
\text { po, em espírito. O líder é } \\
\text { "objetivo" e limita-se aos } \\
\text { "fatos" nas críticas e nos } \\
\text { elogios }\end{array}$ & $\begin{array}{l}\text { O líder não avalia o } \\
\text { grupo nem controla } \\
\text { os acontecimentos, } \\
\text { apenas comenta as } \\
\text { atividades quando } \\
\text { questionado }\end{array}$ \\
\hline
\end{tabular}

Fonte: CHIAVENATO, 2003. 
Como foi possível observar no quadro, os três estilos de liderança são bem distintos entre si. Na liderança autocrática, o líder é autoritário, controla as decisões e determina as funções de cada funcionário, sem permitir que este opine ou sugira algo para realizar sua tarefa. Segundo Serafim (2014), isso se deve ao fato de que essa liderança é algo intuitivo, e para alguns líderes acaba se tornando natural confiar nas próprias experiências e na intuição para determinar como o trabalho deve ser feito.

Já na liderança liberal, o líder concede maior liberdade aos liderados na tomada de decisões, interferindo apenas quando sua opinião é solicitada. Além disso, não supervisiona o trabalho nem incentiva os colaboradores a buscarem o melhor, tanto para eles quanto para a organização, deixando tudo nas mãos dos liderados e fazendo com que ele não seja respeitado.

Por fim, na liderança democrática, o líder, segundo Vieira (2014, p. 8), "procura ser um membro do grupo oferecendo ações para serem executadas e o grupo quem decide quais utilizar". Ou seja, ele permite que o grupo escolha o que deve ser feito, mas também aconselha, sugere ações e sabe como elogiar e motivar o grupo.

Panice, Zanini e Verri (2010) complementam que na liderança autocrática a ênfase é apenas no líder, ou seja, ele comanda e decide pelo grupo; na liberal, a ênfase é no grupo, já que este possui autonomia concedida pelo líder para tomar as decisões; e na democrática tanto o líder quanto o grupo trabalham juntos para atingir as metas da organização, o trabalho em equipe faz a diferença nesse estilo de liderança. No entanto, Chiavenato (2003, p. 125) afirma que:

Na prática, o líder utiliza os três processos de liderança, de acordo com a situação, com as pessoas e com a tarefa a ser executada. O líder tanto manda cumprir ordens, como consulta os subordinados antes de tomar uma decisão, como sugere a maneira de realizar certas tarefas: ele utiliza a liderança autocrática, democrática e liberal. O desafio da liderança é saber quando aplicar qual estilo, com quem e em que circunstâncias e atividades.

Ou seja, o líder pode utilizar os três estilos de liderança; o que vai determinar é o grupo em que ele está inserido, qual tarefa deve 
ser realizada e em que situação. Ele pode mandar os liderados executarem alguma tarefa, mas pedir a opinião deles sobre o assunto, para poderem juntos realizá-la da melhor maneira possível.

Portanto, foi possível perceber as diferenças entre cada estilo de liderança e o fato de que o líder pode escolher um desses três estilos (autocrático, liberal e democrático) ou combiná-los, visto que dependerá da situação, do grupo de que faz parte ou da atividade que precisa ser cumprida. Além disso, é preciso conhecer a diferença entre administrar e liderar e se um complementa o outro de alguma forma, para que isso não prejudique o estilo de liderança no qual o líder tenha escolhido utilizar.

\subsection{Liderar $x$ administrar}

A liderança tem um papel fundamental nas organizações, e é necessário escolher um estilo de liderança adequado ao ambiente de trabalho para que o líder atinja as metas da empresa. Por isso, é importante saber qual a diferença entre liderar e administrar, pois são termos distintos, mas geralmente confundidos, e alguns autores dizem que um complementa o outro.

Segundo Jordão (2013), liderar e administrar são habilidades, ou seja, uma pessoa pode ser um bom líder sem ser um bom administrador e vice-versa. Por ser uma habilidade, há chances de ser aprendida e desenvolvida por cada pessoa. Lacombe (2005, p. 208) afirma que "liderança e administração são dois sistemas de ação complementares, necessários ambos para o êxito de um negócio num ambiente volátil. A liderança complementa a administração, não a substitui". Isto é, eles estão interligados, pois um bom líder precisa entender do processo de administrar, assim como um bom administrador deve saber como liderar os funcionários.

Por outro lado, há autores que apontam como distintos o ato de liderar e o de administrar. Para Endler (2013), a grande diferença entre gestor e líder está na forma como motivam as pessoas que trabalham para eles: o líder se preocupa com o capital humano, motivação de seus colaboradores, ao passo que o administrador está mais focado em utilizar bem as matérias-primas e a tecnologia da organização. Assim, Birkinshaw (2010, apud GUIMARÃES, 2011, p. 5) complementa que "liderança é um processo de influência social: 
ela está preocupada com os traços, estilos e comportamentos dos indivíduos que fazem com que os outros sigam o líder. Já gestão é o ato de reunir pessoas para atingir os objetivos desejados".

Ou seja, o líder é capaz de influenciar as pessoas e com isso fazer com que realizem as tarefas sem ter um pensamento de obrigação. Além disso, se preocupa em desenvolver as habilidades de cada liderado para que se tornem pessoas e profissionais melhores. De modo inverso, o gestor ordena aos funcionários o que deve ser feito, preocupando-se apenas em atingir os objetivos estabelecidos pela organização e utilizar adequadamente os bens disponíveis para a realização das tarefas.

Logo, administrar está relacionado a gerenciar tanto as pessoas quanto os recursos para se alcançarem as metas definidas. Com uma boa administração, as organizações conseguem manter uma posição estratégica no mercado; sem ela, tendem a falir rapidamente. Já liderar significa preocupar-se com as pessoas, guiá-las e instigar nelas a vontade e o comprometimento de executar suas tarefas pelo bem da organização por vontade própria. Daniels e Daniels (2007, apud TAKAHASHI; SARSUR, 2012, p. 5) ressaltam que "a liderança tem foco na mudança, na criatividade e no gerir o inesperado, ou seja, na ação sobre as pessoas e seus relacionamentos e interfaces, enquanto a gestão tem foco na estabilidade, no criar de hábitos, no refinar dos processos, no dia a dia". Ou seja, o líder tem um olhar para o futuro, está inovando a cada dia, faz com que os colaboradores da empresa se sintam reconhecidos por ela, motivados em dar o melhor para que o trabalho seja bem executado, em vez de apenas seguir regras para alcançar os objetivos da organização de acordo com a estratégia proposta e manter uma estabilidade nas suas ações.

No entanto, mesmo que administrar seja diferente de liderar, o gestor precisa ter algumas características de líder, assim como o líder deve saber como administrar os recursos das organizações de maneira eficaz aliado com a motivação dos liderados, pois isso é necessário para a sobrevivência das empresas no atual mercado competitivo em que se encontram.

Portanto, um bom administrador precisa ser um bom líder e vice-versa para o bem da empresa, bem como dos seus subordinados. Não adianta gerir a empresa com precisão se não souber 
estimular e reconhecer as habilidades das pessoas que se gerencia, tampouco saber como motivar os funcionários sem conhecer os procedimentos para utilizar devidamente os recursos da organização. Outro motivo para que isso ocorra é o avanço tecnológico, pois com o auxílio da tecnologia percebe-se que é necessária uma administração flexível, ou seja, a importância da presença do líder que saiba como impulsionar os colaboradores e, ao mesmo tempo, gerenciar as tecnologias de informação que podem ajudar ou interferir no desenvolvimento da sua liderança.

\subsection{Relação entre tecnologia e liderança}

O papel do líder é importante nas organizações e é fundamental que ele escolha corretamente qual estilo de liderança quer desenvolver dentro do seu grupo de trabalho. Além disso, existe diferença entre administrar e liderar: um é voltado mais para a parte gerencial, e o outro, mais preocupado com os colaboradores. Entretanto, no contexto atual em que as empresas estão situadas, é necessário que o líder tenha habilidades de um administrador para que possa gerenciar corretamente a empresa. E algo que pode contribuir ou atrapalhar sua liderança é a tecnologia, isto é, as tecnologias de informação utilizadas na organização por ele podem facilitar ou interferir na maneira como lidera o grupo.

Desde a Revolução Industrial, a tecnologia mantém grande influência no bom desempenho das empresas, mas primeiro é preciso entender o que ela significa. De acordo com Barreto (1995, p. 5), refere-se "a um conjunto de conhecimentos científicos, empíricos e intuitivos, que podem alterar um produto, o processo de produção e o de comercialização deste produto (ou serviço)". Ou seja, trata-se de uma junção de conhecimentos específicos baseados na ciência, experiência e intuição que pode modificar um produto ou serviço, na maneira como produzi-lo e comercializá-lo.

Veraszto et al. (2008) comentam que é difícil estabelecer com precisão uma definição da palavra tecnologia, visto que ao longo da história ela foi interpretada de maneiras distintas, e em momentos diferentes vem atrelada com a história das técnicas, do trabalho e da produção do ser humano. Logo, percebe-se que a tecnologia veio 
se desenvolvendo juntamente com a sociedade e as organizações, aperfeiçoando-se e adquirindo novos conhecimentos.

De acordo com Chiavenato (2003), esse desdobramento da tecnologia estimulou o desenvolvimento das organizações e consolidou a globalização. No entanto, foi na segunda Revolução Industrial, provocada pela cibernética e informática, que se deu a substituição do cérebro humano por softwares complexos, com a invenção do computador. Segundo Bergamini (1994), com a produção automatizada e controlada eletronicamente por meio dos computadores e outras máquinas, a figura do chefe se torna ultrapassada dentro das organizações e se percebe a necessidade de um novo tipo de gestão, com alguém que esteja atento às mudanças e seja participativo. Desse modo, o líder passa a exercer esse papel, aliando seu estilo de liderar a uma boa administração, utilizando os recursos tecnológicos disponíveis na empresa.

Logo, a liderança se torna importante e necessária dentro das organizações, principalmente no atual cenário da globalização, visto que só o líder é capaz de conseguir um bom desempenho dos funcionários devido à maneira como ele os conduz, estimula e ajuda no desenvolvimento de suas habilidades juntamente com o apoio e uso da tecnologia que se tornou ferramenta indispensável no meio organizacional.

De acordo com Chiavenato (2003), a tecnologia no âmbito organizacional é conhecida como informática e por meio dela as empresas implementam banco de dados, sistemas de informação e redes de comunicações integradas. Além disso, é nesse novo ambiente proporcionado pela tecnologia que aparecem as oportunidades de negócios, por causa da rapidez com que as informações são atualizadas e estão disponíveis em tempo real.

Diante disso, as chamadas tecnologias de informação (TI), segundo Santos M. (2013), estão se destacando dentro das organizações pela sua aplicação em trazer flexibilidade, qualidade e inovação. Os investimentos em TI são fundamentais para aquelas que buscam alcançar uma posição estratégica no mercado, pois com a sua modernização ao longo do tempo, trouxeram novos sistemas de gestão com o objetivo de auxiliar no gerenciamento, além de torná-lo mais prático e produtivo. 
Assim, esse avanço nas tecnologias de informação também proporcionou uma evolução no relacionamento com os clientes. Isso se aplica especialmente nas empresas do ramo de serviços, como os empreendimentos hoteleiros que, para Gehlen (2012), dependem da TI para um gerenciamento correto, e as informações em tempo real auxiliam em uma tomada de decisão mais coerente. Além disso, de acordo com Lobianco e Ramos (2004), o aparato tecnológico permite melhor funcionamento de cada setor do hotel, vantagens em manter sua competitividade e diminui os custos.

No entanto, as mudanças que ocorreram dentro dos hotéis com a introdução da TI foram em etapas. Segundo Gehlen (2012), elas tiveram início com o back-office, que proporcionou informações e automatizou os processos administrativos e financeiros. Depois, veio a fidelização dos clientes, ou seja, como a TI está ligada aos computadores e à internet, permitiu a criação de serviços pós-venda que facilitaram maior contato com os clientes, ajudando a conhecer suas necessidades e procurar atendê-las, além de descobrir se algo no gerenciamento foi falho e procurar corrigir. Agora, a fase é a de transição de vendas na qual a tecnologia está modificando a forma como comercializar os apartamentos.

Por isso, no ramo da hotelaria, é essencial a ocorrência de um bom funcionamento e aplicação das tecnologias de informação, em especial da adoção da internet. Isso porque, segundo Chiavenato (2003), ela está quebrando paradigmas, seja na relação empresa-cliente, seja na relação empresa-empresa, por aumentar a velocidade da comunicação, facilitar a maneira de executar negócios, tornar mais rápidos os acordos e retirar fronteiras.

Portanto, a tecnologia é um conjunto de conhecimentos e desde que surgiu ocorreram mudanças em toda a sociedade e principalmente nas organizações, pois modificou a forma de se gerenciarem as empresas, evidenciando a importância de um gestor que saiba tanto administrar os recursos tecnológicos quanto estar atento às mudanças, ser inovador e saber como manter um bom relacionamento dentro do seu grupo de trabalho. A partir disso, a liderança se tornou fundamental, pois o líder, com suas habilidades, consegue ao mesmo tempo administrar e liderar os seus funcionários. Esses conhecimentos que a tecnologia trouxe desde o seu surgimento 
possibilitaram alterar o modo como produzir e comercializar algum produto e, com relação aos serviços, aperfeiçoar a maneira como se relacionar com os clientes.

Com o avanço da tecnologia, surgiram as tecnologias de informação (TI), que se tornaram importantes dentro das organizações, pois sua aplicação proporciona agilidade e qualidade, tornando o gerenciamento mais prático. No ramo da hotelaria, essas tecnologias são necessárias para melhor funcionamento dos setores dentro dos hotéis. Contudo, é preciso entender como funciona a liderança nos empreendimentos hoteleiros, visto que os líderes utilizam essas tecnologias.

\subsection{A liderança no setor hoteleiro}

Como já foi exposto, o papel do líder é preponderante para que as organizações tenham um bom funcionamento, aliado com seu estilo de liderança, que vai determinar a maneira como vai trabalhar com seu grupo. Além disso, ele precisa saber como administrar os recursos e as tecnologias da informação utilizadas na empresa na qual trabalha. Na hotelaria, ou seja, nos empreendimentos hoteleiros que são empresas prestadoras de serviços, é necessário entender a importância da figura do líder como gestor dos diversos setores dentro dos hotéis, diante do cenário atual em que se encontram as organizações.

No entanto, primeiramente é necessário conhecer um pouco da história da hotelaria. Segundo Candeia (2003), ninguém sabe exatamente quando e como ela começou no mundo, mas estudos levam a acreditar que a atividade se iniciou a partir da necessidade natural das pessoas que, quando viajavam, iam à procura de abrigo, apoio e alimentação durante a viagem. Isto é, elas precisavam de algum lugar que pudesse oferecer proteção, ao mesmo tempo que pudessem descansar e se alimentar para poder prosseguir. Essa hospedagem era oferecida pelos moradores dos lugares, nas próprias casas.

Campos e Gonçalves (1998, apud RIBEIRO, 2005) afirmam que a hotelaria evoluiu com a influência dos gregos e romanos, especialmente pelos romanos, devido às estradas que construíam à medida que conquistavam novos territórios, as quais permitiram maior deslocamento das pessoas entre os lugares devido ao intercâmbio comercial. Havia instalações tanto para as classes mais altas quanto para as 
mais simples, mas com a queda do Império Romano as estradas se tornaram perigosas, ocorrendo assim diminuição das viagens e redução do número de hóspedes nas estalagens e pousadas que eram os tipos de estabelecimentos na época. Com o surgimento e expansão do cristianismo, a hospedagem passou a ser oferecida pelas instituições religiosas que eram consideradas mais seguras e confiáveis.

Só a partir do século XII na Europa que essa realidade mudou, pois as viagens voltaram a ser seguras e logo hospedarias se instalaram nas estradas. Foi nesse momento que surgiram leis para regulamentar a hotelaria, principalmente na França e na Inglaterra. Com isso, as estalagens foram adotando e ofertando novos serviços, se desenvolvendo e definindo diferentes tipos de acomodações conforme os diferentes públicos.

Menezes et al. (2011, p. 3) afirmam que "após a Revolução Industrial, houve uma facilidade de deslocamento devido à evolução dos meios de transporte, influenciando assim a expansão da atividade hoteleira". Ou seja, com a chegada das ferrovias e de outros meios de transporte foi possível que grande número de pessoas viajasse com mais facilidade e num curto período de tempo. A partir disso, a hotelaria cresceu mundialmente, pois "a hospedagem passou a ser tratada como uma atividade estritamente econômica a ser explorada comercialmente" (ANDRADE, 2002, apud SANTOS D., 2013, p. 18).

Além disso, a Revolução Industrial fez surgirem novos hotéis em diferentes países, novas técnicas de construção e novas tecnologias que poderiam ser implantadas nos meios de hospedagem. Segundo Ribeiro (2005), no final do século XIX, apareceram homens que buscavam dar uma nova forma e organização aos hotéis. O mais importante deles, considerado o pai da hotelaria, foi César Ritz, que, de acordo com Macedo (2010), criou um novo conceito de hotel com a construção do Hotel Ritz, em Paris, pelo qual melhorou todos os serviços oferecidos, criou os quartos denominados de suítes com banheiro privativo e diferenciou os funcionários pelo uniforme que cada um usava. Ele também é considerado o pioneiro na hotelaria de luxo.

Segundo Santos D. (2013), ocorreu na hotelaria uma transformação radical a partir da Segunda Guerra Mundial. Houve uma expansão mais acelerada da economia mundial, melhoria na renda 
de amplas faixas da população (principalmente nos países mais desenvolvidos da Europa Central, EUA e Canadá), e incremento e melhoria dos sistemas de transporte e comunicação, ou seja, os meios de transporte se tornavam mais rápidos e eficientes, com grande capacidade de pessoas. Para os hotéis se adaptarem, foram sendo construídos ao redor das estações de trens, não mais à beira das estradas. Isso impulsionou, conforme Ribeiro (2005), o desenvolvimento de grandes redes hoteleiras na Europa e nos EUA, conhecidas mundialmente como, por exemplo, Accor, Hilton, Meridien, Sheraton e outras. Essas redes determinaram a evolução dos padrões atuais de hospedagem, equipamentos e serviços.

Como foi possível observar desde o início das civilizações, o ato de acolher alguém em casa, cuidar dessa pessoa e fazer com que ela se sentisse confortável e segura sempre foi importante para os moradores das cidades. No começo era realizado apenas como um favor, porém conforme as cidades foram se desenvolvendo, a atividade passou a ser vista comercialmente como forma lucrativa porque muitas pessoas viajavam tanto a negócios quanto a lazer (apenas aqueles mais ricos). A hotelaria na Europa cresceu ainda mais com a Revolução Industrial, pois possibilitou a criação de novos estabelecimentos, com base na diferença das classes sociais existentes, e modificou a forma de administrá-los devido ao surgimento das redes hoteleiras que padronizaram tanto os serviços quanto a hierarquia dentro dos hotéis. Até então, os estabelecimentos eram administrados pelas famílias que investiam no negócio.

Já no Brasil, os primeiros registros da hotelaria remetem ao período colonial. Vieira da Luz (1999, apud CANDEIA, 2003, p. 16) afirma que nesse período "os viajantes se hospedavam nas casas grandes dos engenhos e fazendas, nos casarões das cidades, nos conventos e, principalmente, nos ranchos que existiam nas beiras das estradas". Ou seja, assim como na hotelaria europeia, nessa época aqui no Brasil era comum as famílias abrigarem os viajantes nas suas casas, fazendas ou qualquer outro lugar que fossem delas, por isso mantinham um quarto de hóspedes. Esses ranchos inicialmente forneciam apenas o serviço de alimentação e um local para dormir, porém depois foram agregando novos serviços que permitiram sua expansão. Nos conventos, pelo seu dever de cari- 
dade, os jesuítas e outras ordens acolhiam grandes personalidades da época e outros hóspedes.

Candeia (2003) comenta que a chegada da corte portuguesa em 1808 e a consequente abertura dos portos no país possibilitaram a entrada de grande fluxo de estrangeiros que aqui vieram exercer diferentes funções, desde a diplomática e até mesmo a comercial. Esse cenário acarretou um aumento na procura por alojamentos, por isso muitos proprietários de casas de pensão, hospedarias e tavernas começaram a utilizar a denominação de hotel nos seus estabelecimentos como forma de atrair esse público estrangeiro que já estava acostumado com o termo já utilizado há muito tempo na Europa, independentemente da quantidade de quartos e da qualidade dos serviços prestados.

No entanto, só no século XX, após a Segunda Guerra Mundial - mais especificamente na década de 1930 -, a hotelaria deu um salto significativo no país. De acordo com Santos D. (2013), isso ocorreu com a implantação de grandes hotéis nas capitais, nas estâncias minerais e nas áreas de apelo paisagístico, cuja ocupação era influenciada pelos cassinos localizados próximo desses hotéis. Todavia, na década de 1940, com a proibição dos jogos de azar, muitos hotéis tiveram que fechar as portas e outros passaram por uma reestruturação para poder continuar funcionando. Segundo Santos D. (2013), apenas a partir de 1963, com incentivos do Banco Central do Brasil, a hotelaria experimentou um novo avanço, porém insuficiente para o desenvolvimento e crescimento do setor no país.

Santos D. (2013) comenta que já na década de 1970 ocorreu a entrada das redes internacionais de hotéis no Brasil impulsionada pela criação da Empresa Brasileira de Turismo (Embratur), hoje transformada em Instituto Brasileiro de Turismo. Frozino (2001) comenta que esse ingresso se deve também ao aumento na realização de viagens e ao desenvolvimento e modernização dos transportes tanto rodoviários quanto aéreos, com o surgimento de estradas unindo novos locais no país e rodovias que foram sendo asfaltadas e duplicadas. Além disso, o país estava se transformando em um polo importante de viagens internacionais graças ao crescimento da economia e aos incentivos da Embratur. Assim, esse mesmo autor complementa que: 
Os principais impactos da entrada das operadoras internacionais no Brasil foram as diversificações dos serviços de hospedagem oferecidos pelos empreendimentos que atuavam no segmento de luxo, e o aumento da profissionalização do setor, com o emprego de mão-de-obra especializada e qualificada. (FROZINO, 2001, p. 23)

Ou seja, as redes hoteleiras internacionais chegaram ao país e mudaram a maneira como estavam sendo construídos os hotéis, oferecidos os serviços por eles e o gerenciamento tanto da empresa quanto dos funcionários. Essas redes trouxeram novas tecnologias, uma nova hotelaria que ainda não era disponibilizada e alcançaram um público que exigia mão de obra mais qualificada para a realização dos serviços. Além disso, impulsionaram a criação das redes hoteleiras nacionais, por causa da grande procura por hospedagens.

No entanto, na década de 1980 o país enfrentou uma crise econômica devido à alta inflação e à instabilidade econômica. Isso acarretou um recuo nos investimentos hoteleiros, apenas projetos que já tinham sido iniciados foram concluídos e entregues. Contudo, Santos D. (2013) afirma que na década de 1990 teve início um processo de mudanças e desenvolvimento de novos empreendimentos hoteleiros, principalmente no ano de 1994 com o Plano Real, que proporcionou um novo crescimento econômico no país, aumentando a demanda hoteleira. Também houve a entrada de fundos de pensão, como os investidores imobiliários no mercado hoteleiro. Candeia (2003) complementa que essa expansão da demanda ocorreu também pelo incremento da renda da população e financiamento de passagens aéreas e pacotes turísticos.

Como foi possível perceber, a hotelaria brasileira demorou a se desenvolver se comparada à hotelaria europeia, pois, para Bertho (2010, p. 14), “a princípio, não havia nenhum interesse em se conhecer o país e sim, em se desbravá-1o". Ou seja, era mais importante conquistar terras, adquirir riquezas e explorar do que conhecer as belezas que o país tinha para oferecer. Além disso, os primeiros meios de hospedagem surgiram exatamente no período colonial, os quais serviam apenas para que viajantes que estavam explorando as terras descansassem para poder continuar a jornada. A administração desses locais era de base familiar, isto é, o chefe 
da família era quem comandava e ditava as regras. Os ensinamentos eram passados de pai para filho e existia a relação de chefe e empregado. E também não havia preocupação com a qualidade dos serviços oferecidos.

Entretanto, a Revolução Industrial proporcionou mudanças na hotelaria brasileira, assim como na hotelaria europeia, devido às inovações tecnológicas que possibilitaram novas maneiras de construção dos hotéis e tecnologias que podiam ser utilizadas por eles. Após a Segunda Guerra Mundial a hotelaria mundial deu um grande salto, pois os meios de transportes estavam mais desenvolvidos e permitiam mais rapidez no deslocamento das pessoas tanto entre cidades quanto entre países. Nesse período, surgiram as grandes redes internacionais de hotéis, que se instalaram no Brasil devido aos incentivos da Embratur. De acordo com Ribeiro (2005, p. 58), "foi preciso que as cadeias estrangeiras trouxessem sua organização, relativamente simples, e seu interesse por regiões nitidamente promissoras para que os hoteleiros tradicionais vissem que uma nova realidade se aproximava".

Ou seja, foi apenas com a chegada das grandes redes internacionais que a hotelaria brasileira percebeu o quanto precisava mudar para conseguir acompanhar o mercado. Não apenas a estrutura física, mas principalmente a forma como gerenciar, visto que ficou evidente que apenas ditar regras e segui-las não manteria o hotel no mercado que estava em constante mudança. Percebeu-se que era necessário alguém que soubesse administrar essas tecnologias e acompanhar as mudanças, além de saber como atingir as metas da organização, porém sem ordenar e dividir as tarefas e esperar os resultados dos seus funcionários, mas sim mostrar como ser feito, interagir com o grupo e trabalhar junto com eles para realizar as tarefas.

Foi nesse momento que o papel do líder se tornou fundamental no gerenciamento dos hotéis, pois os funcionários precisavam de alguém que pudesse guiá-los nesse novo cenário em que os hotéis se encontravam e ainda se encontram. Além disso, Santos D. (2013, p. 26) afirma que o "cenário atual indica que os consumidores já estão se tornando mais familiarizados com as novas tecnologias e exigindo produtos e serviços mais flexíveis, especializados, interativos e inovadores". Isso significa que novas práticas de gestão 
precisam ser utilizadas para atender a esses novos consumidores e que o líder necessita estar atento a essas mudanças para conseguir manter os empreendimentos hoteleiros em posição estratégica.

Portanto, a figura do líder e o papel que exerce dentro da organização são de importância para qualquer tipo de empresa, especialmente hotéis, que são empresas prestadoras de serviços e precisam estar sempre se atualizando para proporcionar qualidade aos clientes. Além disso, ele deve adequar seu estilo de liderança ao seu grupo e saber como administrar as tecnologias de informação, nesse caso as que são utilizadas dentro do hotel, tanto para melhor comunicação interna e distribuição das informações com os sócios, outros gestores e os funcionários quanto com os clientes.

\section{Metodologia}

Segundo Richardson (1999), a abordagem quantitativa caracterizase por quantificar tanto a coleta de informações quanto o tratamento delas por meio de técnicas estatísticas que vão desde as mais simples como percentagem, média e desvio-padrão, até as mais complexas como coeficientes de correlação, análise de regressão e outras. Essa abordagem permite precisão nos resultados, devido a sua objetividade, e evita alterações na análise e interpretação dos dados. Este trabalho se pauta em uma estatística descritiva de tal abordagem.

O método empregado para realização da pesquisa foi o dedutivo. Cervo, Bervian e Silva (2007) afirmam que o ponto de partida desse método é o antecedente, uma verdade universal, e o ponto de chegada é o consequente, uma verdade particular; ou seja, o pesquisador parte de algo complexo para algo mais específico. Além disso, segundo o mesmo autor, o processo dedutivo permite que o estudioso saia do conhecido para o desconhecido com pouca margem de erro, além de seu alcance ser limitado, já que a conclusão não pode ter conteúdos que excedam aqueles já propostos por ele (CERVO; BERVIAN; SILVA, 2007).

Além disso, a pesquisa é do tipo descritivo, visto que descreve cada passo dado pelo pesquisador na realização do estudo e na aplicação das técnicas de pesquisa (SILVA, 2010). Já Heerdt (2007, p. 65) complementa que "as principais técnicas de coleta de dados geralmente utilizadas na pesquisa descritiva são: formulários, en- 
trevistas, questionários, fichas de registro para observação e coleta de dados em documentos".

Logo, o procedimento utilizado foi a pesquisa de campo, que se refere a investigações além da pesquisa bibliográfica e/ou documental, mas também com coleta de dados junto às pessoas, com o auxílio de questionários (FONSECA, 2002, apud GERHARDT; SILVEIRA, 2009).

Com relação à amostra que, de acordo com Dalfovo, Lana e Silveira (2008, p. 4), "tem como corpo uma fração da população delineada na pesquisa", ou seja, uma parte do universo da pesquisa, dentre esses hotéis o pesquisador selecionou 17 para a aplicação da pesquisa, dos quais cinco se mostraram inacessíveis, dois deles prometeram se envolver mas não o fizeram e apenas dez realmente participaram. Além disso, trata-se de uma amostra não probabilística na qual o pesquisador escolhe o elemento do universo (SILVA, 2010). No Quadro 2, é possível observar o tamanho da amostra e o número de respondentes divididos por hotel.

Quadro 2: Universo da pesquisa

\begin{tabular}{|l|l|}
\hline Hotéis & Quantidade de gestores participantes \\
\hline Hotel A & 1 \\
\hline Hotel B & 2 \\
\hline Hotel C & 2 \\
\hline Hotel D & 1 \\
\hline Hotel E & 1 \\
\hline Hotel F & 1 \\
\hline Hotel G & 1 \\
\hline Hotel H & 1 \\
\hline Hotel I & 1 \\
\hline Hotel J & 1 \\
\hline
\end{tabular}

Fonte: Dados da pesquisa.

A coleta de dados foi realizada por meio de questionário, que, para Cervo, Bervian e Silva (2007), é a maneira mais usada para colher dados quantitativos, pois permite medir com mais exatidão o 
que se procura. Kauark, Manhães e Medeiros (2010) complementam que sua confecção é realizada pelo pesquisador e a linguagem deve ser simples e direta para que seja compreendida com mais clareza por quem for responder.

Para a análise dos dados levantados, utilizou-se a análise estatística descritiva dos dados que, segundo Gerarhdt e Silveira (2009, p. 81), "implica processamento de dados, através da geração (normalmente mediante o emprego de técnicas de cálculo matemático), da apresentação (os dados podem ser organizados em gráficos ou tabelas) e da interpretação".

\section{RESUlTAdos DA PESQUISA}

A apresentação dos dados ocorre por meio da explicitação de respostas dos gestores pesquisados referentes às perguntas abertas, bem como acontece pela exposição de gráficos sobre as respostas fechadas, com argumentos a respeito da interpretação de cada dado colhido.

\subsection{Você se considera um líder? Por quê?}

O Quadro 3 demonstra as opiniões dos gestores sobre eles se considerarem líderes. Oito afirmaram positivamente ao questionamento, e quatro não responderam. Em grande parte, as justificativas dadas se resumem no trabalho em equipe que eles realizam com seus colaboradores, contribuindo para atingir os objetivos da empresa; tomam as decisões necessárias sem fugir das suas responsabilidades, são um exemplo para os funcionários; motivam, dão suporte e buscam atender da melhor maneira tanto às necessidades do hotel quanto do grupo sob seu cuidado.

Essa questão é salutar, visto que há autores que afirmam acerca da diferença entre liderar e administrar, e outros que defendem que um complementa o outro. Guimarães (2011) comenta que a liderança combina com um relacionamento humano dinâmico, ao passo que a gestão se relaciona mais com a administração dos recursos materiais presentes na empresa. No entanto, Lacombe (2005) afirma que liderar é diferente de administrar, mas os dois perfis são complementares, já que nem todos os líderes são bons administradores e vice-versa. 
Quadro 3: Você se considera um líder? Se sim, por quê?

\begin{tabular}{|l|l|}
\hline Gestores & Respostas \\
\hline Hotel A & $\begin{array}{l}\text { Sim, pois atuo juntamente com os demais colaboradores, na } \\
\text { linha de frente, não fugindo de minhas responsabilidades, } \\
\text { sendo exemplo e influenciando positivamente os demais. }\end{array}$ \\
\hline Hotel B1 & $\begin{array}{l}\text { Sim, acredito que um líder faz com que a equipe trabalhe } \\
\text { por si só. }\end{array}$ \\
\hline Hotel B2 & $\begin{array}{l}\text { Sim, consigo realizar um trabalho em conjunto com a equi- } \\
\text { pe de forma democrática e positiva. }\end{array}$ \\
\hline Hotel C1 & Não respondeu \\
\hline Hotel C2 & Não respondeu \\
\hline Hotel D & $\begin{array}{l}\text { Sim, porque consigo alcançar os objetivos dentro da empre- } \\
\text { sa junto com meus colaboradores. }\end{array}$ \\
\hline Hotel E & $\begin{array}{l}\text { Sim, porque motivo, porque treino, criei um bom clima de } \\
\text { trabalho, dou suporte a minha equipe, faço as tarefas deles } \\
\text { e porque ouço as pessoas. }\end{array}$ \\
\hline Hotel F & $\begin{array}{l}\text { Sim, pois a tomada de decisões é feita em conjunto com } \\
\text { cada setor, para assim atender da melhor forma as necessi- } \\
\text { dades do hotel e dos colaboradores. }\end{array}$ \\
\hline Hotel G & $\begin{array}{l}\text { Sim, porque sei liderar muito bem minha equipe, tomo sem- } \\
\text { pre as decisões que devem ser tomadas e não me hesito em } \\
\text { enfrentar as decisões mais complexas. }\end{array}$ \\
\hline Hotel H & Não respondeu \\
\hline Hotel I & Não respondeu \\
\hline Hotel J & Sim, porque comando a empresa. \\
\hline
\end{tabular}

Fonte: Dados da pesquisa.

Ou seja, liderar e administrar apresentam diferenças, pois o líder é mais focado nas pessoas que fazem parte do seu grupo, em conhecê-las e ajudá-las a desenvolver suas competências, bem como no trabalho em equipe, inspirando confiança nos subordinados. Nesse sentido, no cenário atual do mercado os gestores, além de serem bons administradores, precisam saber liderar e apresentar características de um líder para manter a empresa competitiva. 
Portanto, entende-se que os gestores participantes da pesquisa podem ser considerados líderes tendo em vista as justificativas dadas por eles. É possível enxergar nas respostas a principal característica que um líder deve possuir: a preocupação com os funcionários e em atingir os objetivos da empresa com o trabalho de equipe, o que caracteriza uma liderança mais relacional.

\subsection{Elenque de um a cinco suas características que mais se destacam na realização do seu trabalho}

No Quadro 4 estão dispostas as cinco características que mais se destacam na realização do trabalho dos gestores. Quatro deles não responderam à pergunta, devido à questão ter passado despercebida enquanto respondiam e ao fato alegado por eles de que respondiam no momento em que tinham algum tempo livre durante o trabalho.

Quadro 4: Características que mais se destacam na realização do seu trabalho

\begin{tabular}{|c|c|}
\hline Gestores & Respostas \\
\hline Hotel A & $\begin{array}{l}\text { Trabalho em equipe } \\
\text { Motivação } \\
\text { Cortesia } \\
\text { Educação } \\
\text { Dedicação }\end{array}$ \\
\hline Hotel B1 & $\begin{array}{l}\text { Espírito de equipe } \\
\text { Foco nos resultados } \\
\text { Humildade } \\
\text { Empatia } \\
\text { Confiança }\end{array}$ \\
\hline Hotel B2 & $\begin{array}{l}\text { Responsabilidade pela equipe } \\
\text { Encorajar a criação } \\
\text { Acompanhamento de desempenho } \\
\text { Dar o exemplo } \\
\text { Gerar confiança para alcance de resultados }\end{array}$ \\
\hline Hotel C1 & Não respondeu \\
\hline Hotel C2 & Não respondeu \\
\hline
\end{tabular}




\begin{tabular}{|l|l|}
\hline Gestores & Respostas \\
\hline Hotel D & $\begin{array}{l}\text { Comprometimento } \\
\text { Agilidade } \\
\text { Eficácia } \\
\text { Bom senso } \\
\text { Atendimento }\end{array}$ \\
\hline Hotel E & $\begin{array}{l}\text { Motivação } \\
\text { Hiperatividade } \\
\text { Proatividade } \\
\text { Qualidade } \\
\text { Profissionalismo }\end{array}$ \\
\hline Hotel F & $\begin{array}{l}\text { Paciência } \\
\text { Saber ouvir } \\
\text { Flexível } \\
\text { Trabalhar em equipe } \\
\text { Ser líder }\end{array}$ \\
\hline Hotel G & $\begin{array}{l}\text { Foco } \\
\text { Trabalho em equipe } \\
\text { Liderança } \\
\text { Criatividade } \\
\text { Comunicativo }\end{array}$ \\
\hline Hotel H & Não respondeu \\
\hline Hotel I & $\begin{array}{l}\text { Tranquilidade para tomar decisões e resolver situa- } \\
\text { ções } \\
\text { Trabalho em equipe } \\
\text { Bom relacionamento } \\
-\end{array}$ \\
\hline Hotel J & Não respondeu \\
\hline
\end{tabular}

Fonte: Dados da pesquisa.

Com relação às características que o líder apresenta, no início acreditava-se que ele já nascia com elas: as pessoas que possuíam o dom da liderança eram consideradas superiores. No entanto, com a chegada da Revolução Industrial, no século XVIII estudos mostraram que era possível formar líderes por meio das características e atributos de grandes personalidades. Ou seja, a visão sobre o líder foi se modificando e sendo aperfeiçoada com o passar dos anos desde 
o surgimento do termo. Entretanto, algo que nunca mudou foi sua importância dentro das organizações, sem importar se suas características são natas ou foram desenvolvidas com o tempo, pois só o líder consegue atingir os objetivos das empresas se preocupando também com seus liderados.

Por isso, as características descritas pelos gestores são consideradas de líder, tanto as próprias quanto as adquiridas, visto que demonstraram preocupar-se com sua equipe, priorizando paciência, trabalho em equipe, flexibilidade, comprometimento, dedicação, responsabilidade e acompanhamento de desempenho. A isso se acrescenta o fato de gerarem confiança em seus funcionários, serem humildes, educados, demonstrarem empatia e tranquilidade para resolver situações.

\subsection{Tomada de decisões}

Observa-se que no momento da tomada de decisões a alternativa que mais se destaca é a letra D (82\%), em que o gestor concentra as decisões nele, mas permite que seus funcionários tenham liberdade para sugerir ideias e expor suas opiniões. Já na alternativa C, que corresponde a 18\%, o gestor conduz e posiciona seu grupo, estimulando a participação dos funcionários na tomada de decisões.

Gráfico 1: Tomada de decisões

\section{Tomada de decisões}

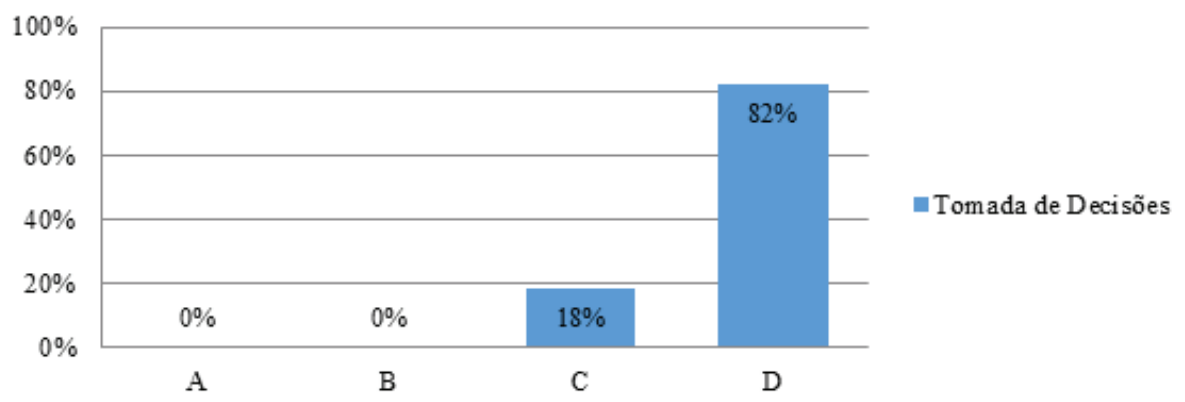

Fonte: Dados da pesquisa.

De acordo com Chiavenato (2003), para que obtenha sucesso dentro do seu ambiente de trabalho, o líder precisa definir um estilo 
de liderança, ou seja, como vai conduzir a equipe, de que maneira vai se comportar e como isso afetará o grupo. Com relação à tomada de decisões, no estilo autocrático ele concentra as decisões e impõe suas ordens ao grupo; no liberal, concede aos funcionários o poder e total liberdade na tomada de decisões; já no democrático, conduz e posiciona o grupo, estimulando a participação dos funcionários na tomada de decisões. Todavia, o líder pode utilizar os três de estilos de liderança juntos, como afirma Chiavenato (2003): ele pode concentrar as decisões em si mesmo, mas pede aos funcionários que exponham suas opiniões e sugiram ideias para realizar determinada tarefa da melhor maneira possível, pois o que vai determinar é o grupo em que ele está inserido, qual tarefa deve ser feita e a situação.

Logo, é possível identificar, segundo as respostas dos gestores, que a alternativa $\mathrm{D}$ se refere à junção dos três estilos de liderança no momento em que o líder precisa tomar decisões, pois permite que os funcionários tenham liberdade para opinar e sugerir ideias, mas as decisões finais são concentradas nele. Já a alternativa C diz respeito ao estilo democrático pelo qual o líder dirige e posiciona seu grupo, além de estimular a participação dos funcionários na tomada de decisões. Ou seja, os respondentes da pesquisa utilizam os três estilos de liderança juntos para tomar as decisões com a sua equipe.

\subsection{Comportamento com os funcionários}

O Gráfico 2 apresenta as respostas dos gestores mediante a maneira como se comportam com os funcionários no ambiente de trabalho. A alternativa A, com $42 \%$, é a que mais se destaca e sinaliza que o gestor tem um relacionamento honesto, de amizade, se preocupa em ouvir seus colaboradores e os ajuda a desenvolverem suas habilidades e capacidades. Já a alternativa D (33\%) corresponde a um bom relacionamento com os funcionários, sabendo o momento certo em deixá-los à vontade e aqueles em que deve ser mais rígido. $\mathrm{Na}$ alternativa E (25\%) o gestor diz o que sua equipe deve fazer, mas permite que ela opine, além de ajudá-la a desenvolver suas habilidades. 
Gráfico 2: Comportamento com os funcionários

Comportamento com os funcionários

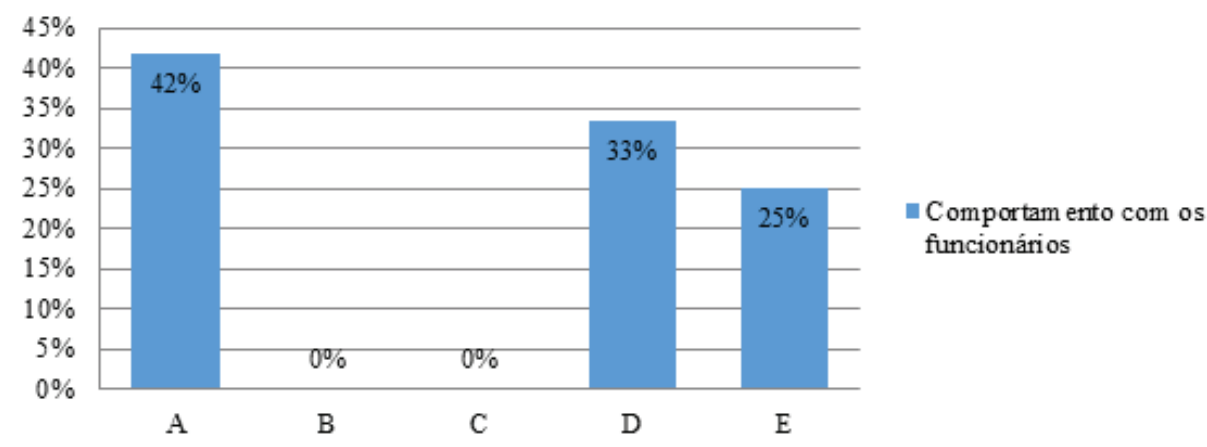

Fonte: Dados da pesquisa.

Com relação ao comportamento do líder para com os liderados, cada estilo de liderança apresenta características distintas. No autocrático, ele é autoritário, controla as decisões e determina as funções de cada funcionário, sem conversar ou interagir com eles; no liberal, deixa o grupo bastante à vontade, sem controle, com liberdade para executar as tarefas no ritmo dele, só participando quando é solicitado; já no democrático, mantém um relacionamento de amizade, de maneira educada, honesta e espontânea, preocupa-se em ouvir seus funcionários e os auxilia a desenvolverem suas competências (CHIAVENATO, 2003).

É possível perceber pelas respostas que a alternativa A corresponde ao estilo democrático, ou seja, a maioria dos gestores mantém um bom relacionamento com sua equipe de trabalho, priorizando a educação, a amizade e a honestidade entre eles, além de se preocupar em ouvir o que as pessoas têm a dizer e em ajudá-las a se desenvolverem. Já as alternativas D e E são uma mistura dos três estilos de liderança, visto que tais líderes mantêm um bom relacionamento com seus liderados, mas dizem o que devem fazer, sabem o momento certo em que precisam ser mais rígidos e permitem que tenham liberdade para opinar, além de ajudá-los a se desenvolverem.

Portanto, o comportamento dos gestores com sua equipe se adequa mais ao estilo de liderança democrático, no qual há entre eles um relacionamento de companheirismo e de honestidade, 
visando ao trabalho em equipe, em que o liderado tem confiança no líder. Porém, alguns gestores utilizam os três estilos juntos com seus colaboradores.

\subsection{Divisão das tarefas}

Pode-se observar que no Gráfico 3, referente ao momento de dividir as tarefas para cada membro da equipe, prevaleceu a alternativa A, com $42 \%$, a qual defende ser o gestor aquele que determina qual tarefa cada um deve executar. A alternativa D (33\%) sustenta que o gestor determina as tarefas, mas permite que os colaboradores opinem sobre sua decisão; por fim, na alternativa C (25\%), o gestor sugere alternativas para o grupo escolher e a divisão fica a critério do grupo.

Gráfico 3: Divisão das tarefas

Divisão das tarefas



Fonte: Dados da pesquisa.

Em cada estilo de liderança, o líder se comporta de maneira diferente, especialmente no momento em que precisa definir uma tarefa para cada membro da equipe. Partindo desse pressuposto, a alternativa A, que obteve o maior percentual nas respostas dos gestores, faz parte do estilo autocrático; a alternativa $D$ é a junção dos três estilos de liderança; por fim, a alternativa $C$ pertence ao estilo democrático.

Logo, podemos perceber que a maioria dos gestores concentra neles a divisão das tarefas, sem dar liberdade para os funcionários opinarem ou sugerirem algo para melhorar. Contudo, há aqueles 
que determinam as tarefas e permitem que as pessoas digam sua opinião sobre as escolhas feitas. E ainda há os que deixam a divisão a critério do grupo, só dando sugestões para o grupo escolher.

\subsection{Estilo de liderança}

Em relação a qual é o seu estilo de liderança, a alternativa D se destaca com $64 \%$, e refere-se a uma mistura dos três estilos. Entretanto, há aqueles gestores que se encaixam na alternativa C (27\%), referente ao estilo democrático, no qual o líder aconselha e ouve os funcionários. Já na alternativa A (9\%), o gestor afirma que seu estilo de liderança é o autocrático: controla as decisões e determina as funções de cada funcionário.

Gráfico 4: Estilo de liderança

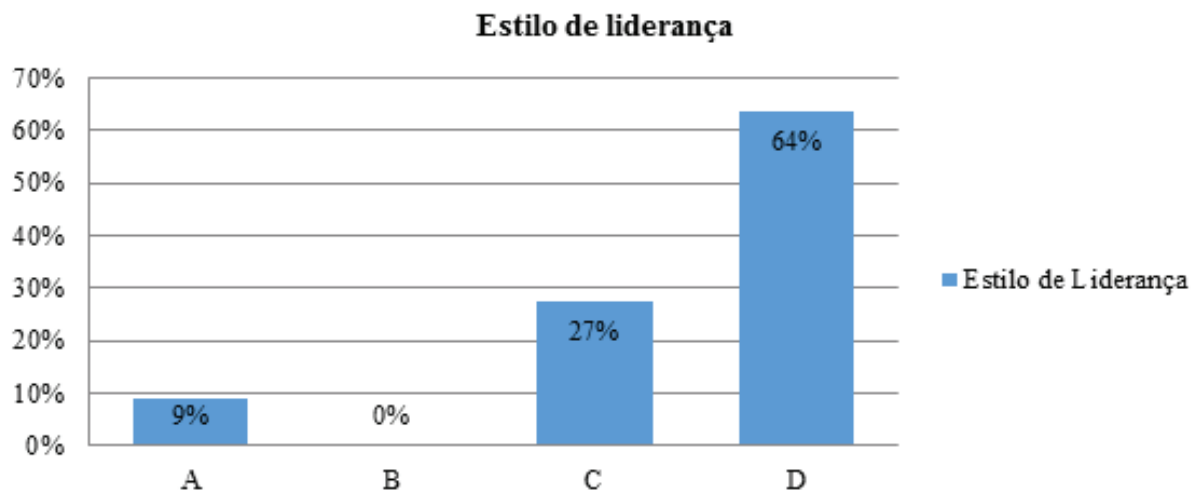

Fonte: Dados da pesquisa.

Os estilos de liderança podem ser divididos em autocrático, liberal (laissez-faire) e democrático. No entanto, os líderes podem utilizar os três estilos junto com sua equipe de trabalho, uma vez que eles se adequam ao grupo em que está inserido, ao que deve ser feito e ao ambiente de trabalho, ou seja, às situações que podem acontecer e acontecem.

Portanto, conforme as respostas dos gestores, eles utilizam os três estilos de liderança, e isso é fundamental na hotelaria, visto que o produto do hotel é o serviço e para que seus funcionários atendam 
bem aos hóspedes, precisam de um líder flexível, que consiga se adaptar à equipe e a qualquer problema que possa surgir.

\subsection{Quanto você acha que o grupo em que está inserido in- terfere no seu estilo de liderança}

Há grande diversidade nas respostas dos gestores referente a quanto o grupo em que eles estão inseridos interfere no seu estilo de liderança. A opção "Regular" se destaca com 33\% das opiniões, seguida por "Pouco" e "Não interfere" (25\% cada); apenas 17\% afirmam que a equipe interfere muito no seu estilo de liderança.

Gráfico 5: O quanto o grupo interfere no seu estilo de liderança

\section{O quanto o grupo interfere no seu estilo de liderança}



Fonte: Dados da pesquisa.

O grupo no qual o gestor está inserido, isto é, sua equipe de trabalho, pode interferir ou não no seu estilo de liderança, pois vai determinar qual o melhor a ser utilizado por ele no seu ambiente de trabalho, já que precisa manter o grupo em harmonia e motivado para que as tarefas sejam executadas corretamente.

É fundamental que o gestor se adeque à equipe, saiba escutá-la, seja flexível diante de qualquer situação que possa aparecer, demonstre comprometimento, principalmente no setor de serviços, em especial na hotelaria, visto que os funcionários têm de lidar diretamente com o público e precisam estar satisfeitos com seu 
ambiente de trabalho para que o serviço seja bem prestado. Logo, conforme as respostas dos gestores, a maioria afirmou que o grupo interfere, sim, no seu estilo de liderança, alguns disseram que de forma regular (nem muito, nem pouco), e outros, pouco.

\subsection{Quanto você acha que as tarefas a serem executadas interferem no seu estilo de liderança}

Percebe-se que $33 \%$ dos gestores afirmaram que as tarefas interferem no seu estilo de liderança de maneira regular, isto é, nem muito nem pouco; $25 \%$ disseram que ou não interferem ou interferem pouco; e 17\% deles responderam que as tarefas afetam muito o seu estilo de liderança.

Gráfico 6: O quanto as tarefas interferem no seu estilo de liderança

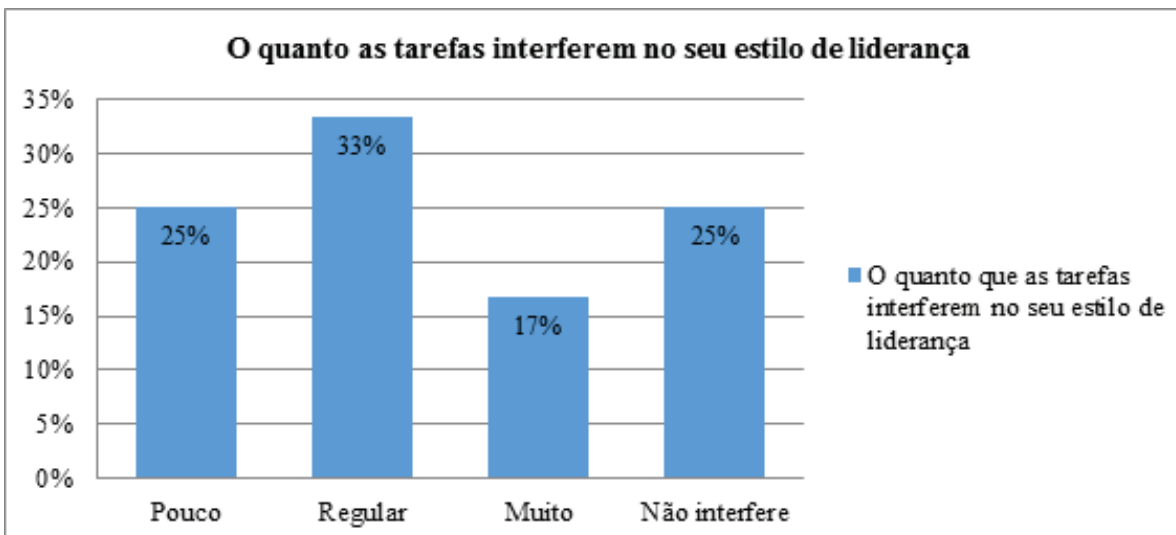

Fonte: Dados da pesquisa.

Além da equipe em que os gestores estão inseridos, as tarefas que precisam ser executadas por eles também podem ou não interferir no estilo de liderança, visto que vão variar dependendo da organização. Na hotelaria, isso ocorre conforme o tipo de hotel, sua estrutura organizacional, sua categoria, seu público-alvo, o setor que o gestor administra, os recursos disponíveis e os serviços ofertados. O gestor precisa encontrar a melhor maneira para executar as tarefas destinadas a ele e sua equipe, mas também adequar o seu estilo de liderança para que não afete ou prejudique o ambiente de trabalho e as tarefas sejam bem realizadas ou os serviços sejam bem oferecidos. 
Portanto, os gestores participantes da pesquisa apontaram que as tarefas interferem de maneira regular ou pouco ou não interferem no seu estilo de liderança. Isso significa que eles realizam as atividades juntamente com sua equipe e que o seu estilo de liderança sofre pouca ou nenhuma mudança durante o cumprimento delas dentro do setor que gerencia no hotel.

\subsection{Quanto você acha que seu estilo de liderança influencia a} gestão do setor no qual você trabalha

Os gestores foram questionados sobre quanto seu estilo de liderança influencia a gestão do setor em que trabalha, e $75 \%$ afirmaram influencia muito, como mostra o Gráfico 7. O estilo de liderança que o gestor utiliza no seu ambiente de trabalho refere-se, de acordo com Chiavenato (2003), à maneira como se comporta perante os funcionários, isto é, como lidera a equipe e como isso afeta o grupo. Portanto, o gestor precisa utilizar aquele estilo que melhor se adequa ao grupo em que está inserido, à tarefa que será realizada por ele e ao seu ambiente de trabalho.

Gráfico 7: O quanto seu estilo de liderança influencia na gestão do setor em que você trabalha

\section{O quanto seu estilo de liderança influencia a gestão do setor em que} você trabalha

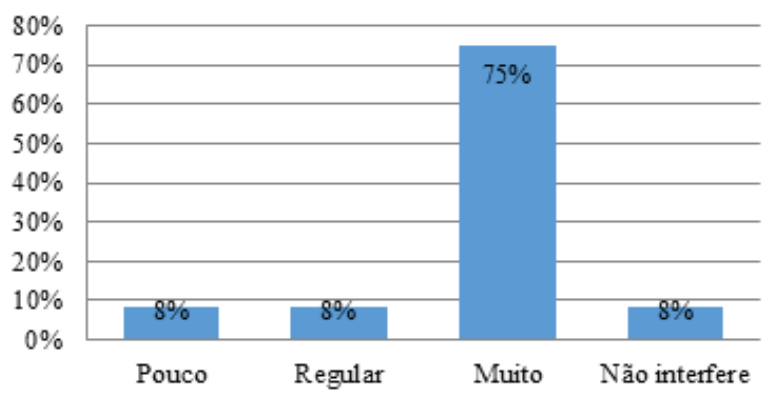

$\because$ O quanto que seu estilo de liderança influencia na gestão do setor em que você trabalha

Fonte: Dados da pesquisa.

Por isso, os gestores afirmaram que seu estilo de liderança influencia muito a gestão do setor em que trabalham dentro do hotel, visto que ele é fundamental na liderança de sua equipe, na 
execução de suas atividades e na manutenção da harmonia no ambiente de trabalho.

\subsection{Quanto você acha que seu estilo de liderança influencia o hotel no qual você trabalha}

Diante do exposto no Gráfico 8, com relação a quanto o estilo de liderança utilizado pelos gestores influencia o hotel em que trabalham, observa-se que $67 \%$ alegaram que influencia muito; apenas $17 \%$ deles afirmaram que não interfere ou influencia de maneira regular (nem muito nem pouco).

Gráfico 8: O quanto seu estilo de liderança influencia o hotel

\section{O quanto seu estilo de liderança influencia o hotel}

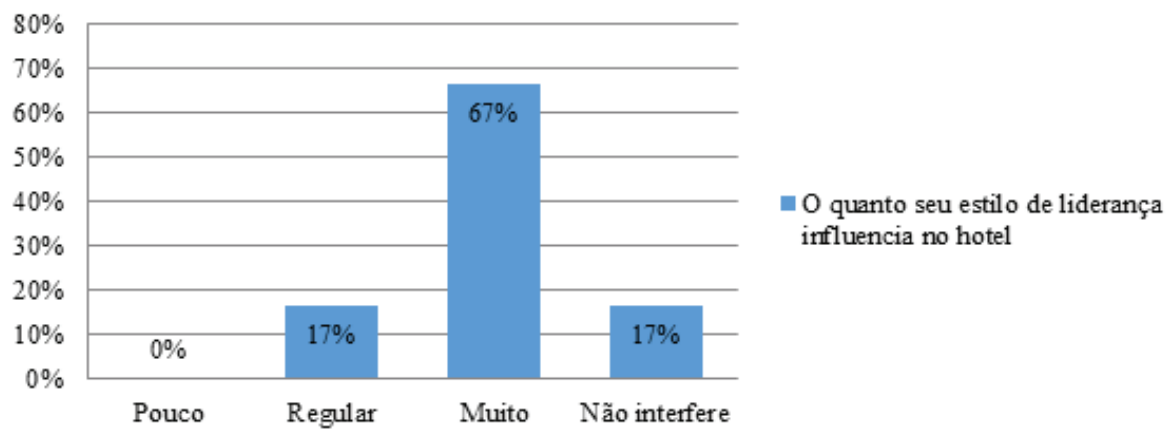

Fonte: Dados da pesquisa.

Castelli (2000, p. 18) argumenta que "a sobrevivência da empresa hoteleira depende da capacidade, agilidade e flexibilidade dos gestores de se adaptarem constantemente aos desejos, necessidades e expectativas de seus consumidores". Ou seja, nesse cenário de alta concorrência no setor, em que o diferencial está na qualidade dos serviços oferecidos aos hóspedes, o papel dos gestores é fundamental, pois precisam estar atentos às mudanças e se adaptar para melhor atender os clientes.

Assim, o estilo de liderança influencia muito dentro do hotel em que os gestores trabalham: ele vai definir o melhor comportamento que devem adotar dentro do seu ambiente de trabalho, seja na tomada 
de decisões, seja em determinada situação, seja em como manter a equipe unida, confiante e motivada, a fim de proporcionar um serviço de qualidade aos consumidores. A isso se soma o fato de que vai ajudar a conservar a competitividade do hotel ante o mercado atual.

\subsection{0 quanto que você acha que seu estilo de liderança in- fluencia a motivação dos seus funcionários na execução das tarefas}

Na opinião dos gestores sobre quanto o seu estilo de liderança influencia a motivação dos seus funcionários na execução das tarefas, $67 \%$ afirmaram que influencia muito no momento da realização das tarefas que são destinadas a eles; $17 \%$ disseram que exerce influência de forma regular (nem muito, nem pouco); $8 \%$ responderam que influencia pouco, o mesmo percentual dos que apontaram que não interfere.

Gráfico 9: O quanto seu estilo de liderança influencia a motivação dos seus funcionários

O quanto seu estilo de liderança influencia a motivação dos seus funcionários

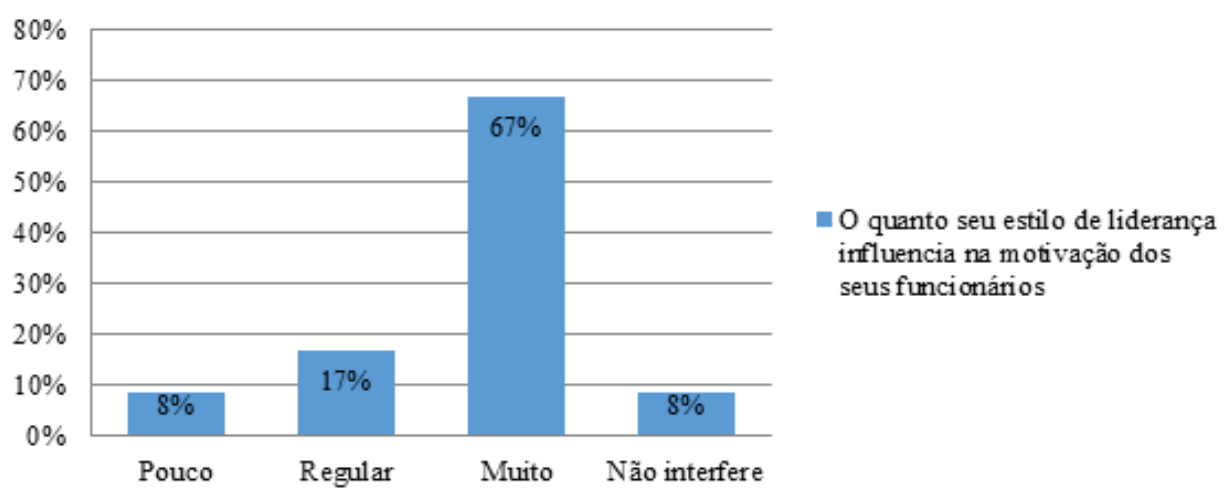

Fonte: Dados da pesquisa.

O modo como o gestor lidera sua equipe influencia a motivação dela para realizar as atividades, pois cada estilo de liderança apresenta uma maneira diferente. Adotando o estilo autocrático, o líder impõe suas ordens ao grupo e isso não permite que seus integrantes sejam espontâneos e estabeleçam amizades, fazendo com 
que realizem as tarefas sem nenhuma satisfação; com o estilo liberal, permite que a equipe fique à vontade na tomada de decisões, de modo que execute as atividades ao acaso pelo individualismo entre eles e com pouco respeito ao líder.

Adotando o estilo democrático, o líder guia sua equipe, permitindo que ela opine, o que gera um clima de satisfação no ambiente de trabalho. Ressalta-se que ele também pode utilizar os três estilos de liderança juntos para motivar os funcionários. Para isso, torna-se salutar que o gestor se atente ao grupo em que está inserido para utilizar adequadamente o estilo de liderança, visto que a maneira como lidera a equipe tem influência na motivação dela na realização do trabalho.

\subsection{Enumere os três principais elementos que você conside- ra como desafiadores na sua gestão}

Percebe-se que os gestores apresentam uma coerência nos elementos considerados por eles como os mais desafiadores da sua gestão dentro do setor em que trabalham no hotel, especialmente: manter a equipe motivada e o espírito de equipe; lidar com a internet e redes sociais; e lidar com o hóspede, pois cada um apresenta uma necessidade diferente e nem sempre é possível atendê-los.

Apesar de adequar o seu estilo de liderança à equipe em que está inserido, ao seu ambiente de trabalho e às tarefas que devem ser executadas, os gestores enfrentam alguns desafios no momento de desenvolver seu estilo de liderança. Segundo Guimarães (2011), o principal é estimular as pessoas nas empresas a mostrar o seu potencial, valor e talento. Ou seja, mesmo que o gestor esteja usando o estilo de liderança apropriado, ele precisa fazer com que cada membro desenvolva e demonstre suas habilidades. No entanto, alguns apresentam resistência, seja por ser um membro antigo da equipe e pensar que é melhor continuar na mesma rotina, seja por insegurança, seja por pensar que é apenas sua obrigação e não precisam mostrar o que são capazes de fazer.

Ademais, a chegada da tecnologia transformou o ambiente organizacional, uma vez que modificou a forma de se gerenciarem as empresas. Além de saber administrar os recursos tecnológicos disponíveis, o gestor precisa estar atento às mudanças e manter um bom relacionamento no ambiente de trabalho. Com a tecnologia, surgiu a internet, que facilita e torna mais rápida a comunicação entre empresa e consumidor; entretanto, nem sempre os funcionários a utilizam apenas para assuntos da organização. Por isso, quanto 
mais cuidadoso o gestor for com relação à sua equipe, melhor para o próprio andamento das atividades, sobretudo a hoteleira, em virtude do seu dinamismo particular.

O gestor hoteleiro encontra outro desafio que é o de atender a todas as necessidades dos hóspedes, já que cada um apresenta uma demanda diferente e, mesmo que ele se esforce dificilmente consegue atender plenamente. Também é essencial cuidar administrativamente do hotel, fazer manutenção em cada setor e no tempo certo para que assegure a qualidade nos serviços ofertados.

Quadro 4: Os três principais elementos desafiadores na sua gestão

\begin{tabular}{|l|l|}
\hline Gestores & Respostas \\
\hline Hotel A & $\begin{array}{l}\text { Manter a equipe motivada, coesa } \\
\text { Manter colaboradores felizes, em espírito de grupo } \\
\text { Extrair de cada colaborador o melhor de si }\end{array}$ \\
\hline Hotel B1 & $\begin{array}{l}\text { Hotel antigo } \\
\text { Equipe antiga (resistência a mudança) }\end{array}$ \\
\hline Hotel B2 & Não respondeu \\
\hline Hotel C1 & Não respondeu \\
\hline Hotel C2 & Não respondeu \\
\hline Hotel D & $\begin{array}{l}\text { Manter uma boa ocupação } \\
\text { Equipar o hotel, pois depende do diretor } \\
\text { Manter um bom relacionamento entre os funcionários e a } \\
\text { empresa }\end{array}$ \\
\hline Hotel E & $\begin{array}{l}\text { Manter a motivação dos colaboradores } \\
\text { Pouca vontade de crescimento }\end{array}$ \\
\hline Hotel F & $\begin{array}{l}\text { Lidar com pessoas, pelas características de cada um } \\
\text { Lidar com internet/redes sociais } \\
\text { Lidar com o público/hóspede, pois cada um tem uma ne- } \\
\text { cessidade diferente e nem sempre podemos atendê-los }\end{array}$ \\
\hline Hotel G & Não respondeu \\
\hline Hotel H & Não respondeu \\
\hline Hotel I & Não respondeu \\
\hline Hotel J & $\begin{array}{l}\text { Equipe } \\
\text { Manutenção }\end{array}$ \\
\hline
\end{tabular}

Fonte: Dados da pesquisa. 
Portanto, os desafios descritos pelos gestores são frequentes no cenário atual do mercado em que a hotelaria está inserida. Eles precisam estar atento às mudanças a fim de saber como cuidar da equipe e manter o hotel competitivo ante os concorrentes. Além disso, é necessário que saibam utilizar corretamente a internet e a tecnologia dentro do hotel e que orientem a equipe para evitar distrações durante o cumprimento das tarefas.

\subsection{Em relação à tecnologia, quanto que a organização tem de abertura para a tecnologia}

Em relação a quanto a organização tem de abertura para a tecnologia, 70\% dos gestores afirmaram que no hotel em que trabalham há muita abertura para a tecnologia; os outros $30 \%$ se dividem entre regular $(20 \%)$ e pouco $(10 \%)$. Nas organizações, a tecnologia diz respeito à informática, pela qual se implementam banco de dados, sistemas de informação e redes de comunicações integradas. Isso permite novas oportunidades de negócios para as empresas, pois as informações são atualizadas rapidamente e disponíveis em tempo real.

Gráfico 10: Quanto que a organização tem de abertura para a tecnologia Quanto que a organização tem de abertura para a tecnologia

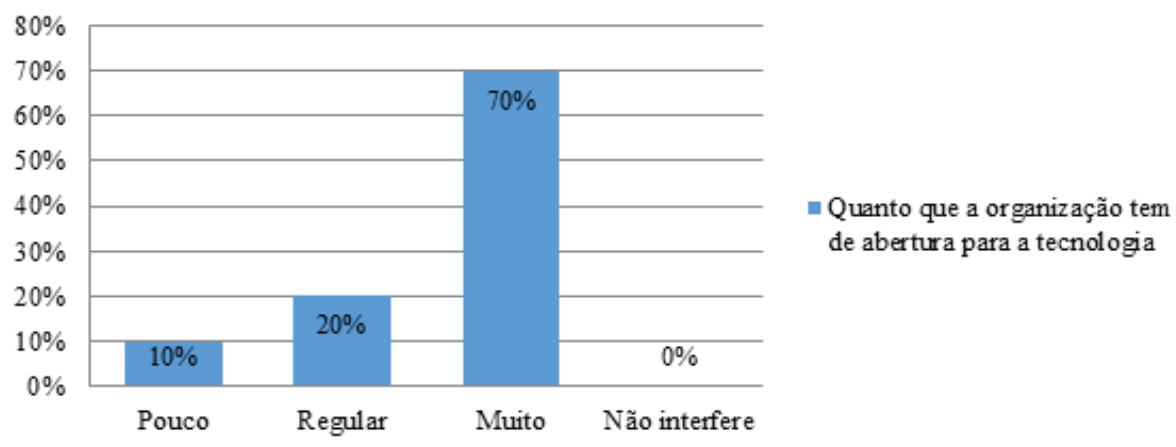

Fonte: Dados da pesquisa.

Bassotto (2008) comenta que o crescente desenvolvimento da tecnologia afeta diretamente a hotelaria, modificando a maneira como o trabalho é executado. Com esse avanço surgiram as tecnolo- 
gias de informação (TI), que tornaram o gerenciamento mais rápido. Vale destacar que na hotelaria essas tecnologias são essenciais para um bom funcionamento dos setores dentro dos hotéis. Além disso, proporcionaram um avanço no relacionamento com os clientes e tornaram os hotéis mais competitivos.

Por isso, é necessária essa abertura para a tecnologia dentro do hotel porque contribui para melhor gerenciamento, novas oportunidades de negócios, rapidez na comunicação entre os funcionários e com os clientes, além de tornar o hotel mais competitivo diante dos concorrentes e do mercado em que está inserido.

\subsection{Que tecnologias afetam o desenvolvimento da sua lide- rança?}

Podemos ver pelo Quadro 5 que a maioria dos gestores afirmou que nenhuma compromete seu estilo de liderança com sua equipe; apenas alguns alegaram que a internet interfere e outro respondente que relatou que os sistemas utilizados na recepção, alimentos e bebidas e almoxarifado podem afetar o seu estilo de liderança.

Quadro 5: As tecnologias que afetam o desenvolvimento da sua liderança

\begin{tabular}{|l|l|}
\hline Gestores & Respostas \\
\hline Hotel A & Nenhuma \\
\hline Hotel B1 & Os sistemas de recepção, alimentos e bebidas, almoxarifado \\
\hline Hotel B2 & Nenhuma \\
\hline Hotel C1 & Nenhuma \\
\hline Hotel C2 & Nenhuma \\
\hline Hotel D & $\begin{array}{l}\text { Busco muita coisa na internet para ver o que tem de novo no } \\
\text { mercado e o que procuro melhorar }\end{array}$ \\
\hline Hotel E & Nenhuma \\
\hline Hotel F & Apenas a internet \\
\hline Hotel G & Nenhuma \\
\hline Hotel H & Nenhuma \\
\hline Hotel I & Nenhuma \\
\hline Hotel J & Nenhuma \\
\hline
\end{tabular}

Fonte: Dados da pesquisa. 
Embora a tecnologia possibilite auxiliar o gestor no ambiente de trabalho e na execução das tarefas, bem como das dos funcionários, além de ajudar a manter um bom relacionamento com os clientes, agilizar a comunicação interna e externa e proporcionar novos negócios para o hotel, ela pode interferir no seu estilo de liderança: muitos funcionários podem utilizar a tecnologia para algo pessoal, em vez de estar atentos ao trabalho, o que pode alterar o clima do ambiente de trabalho.

No entanto, de acordo com as respostas dos gestores, dentro do setor em que trabalha a tecnologia não afeta na maneira de liderarem as equipes, pelo contrário, ela contribui na realização das tarefas. Logo, percebe-se que a tecnologia é bem utilizada tanto pelo gestor quanto pelos seus funcionários dentro do seu setor e do hotel. Além disso, o estilo de liderança usado pelo gestor não está sendo afetado por ela, contribuindo na execução de suas tarefas e no gerenciamento do setor.

\subsection{Em sua opinião, as tecnologias usadas pelo hotel aju- dam ou prejudicam a sua gestão? Por quê?}

O Quadro 6 mostra a opinião dos gestores em relação a se as tecnologias usadas pelo hotel ajudam ou prejudicam a sua gestão e por quê. Com exceção dos quatro gestores que não responderam, todos os outros afirmaram que as tecnologias contribuem na gestão por diversos motivos, dentre eles: tornam o trabalho mais fácil e dinâmico; melhoram a gestão; facilitam a comunicação e ajudam no treinamento da equipe; e facilitam o desenvolvimento da equipe. Todavia, alguns disseram também que as tecnologias só atrapalham no momento em que os funcionários esquecem ou param as atividades para usá-las de maneira inadequada.

Portanto, a tecnologia aliada ao estilo de liderança contribui para um bom desenvolvimento do hotel e, além disso, ajuda o gestor no seu ambiente de trabalho, pois otimiza o trabalho, a comunicação se torna mais rápida entre ele e a equipe e possibilita aperfeiçoar a maneira como se relacionar com os clientes. Mas também o gestor precisa se manter atento para que seus funcionários não utilizem de maneira errada a tecnologia. 
Quadro 6: As tecnologias usadas pelo hotel na sua gestão

\begin{tabular}{|l|l|}
\hline Gestores & Respostas \\
\hline Hotel A & Ajudam, pois dão dinamismo e facilitam o trabalho \\
\hline Hotel B1 & Ajudam, pois as tecnologias facilitam o trabalho das equipes \\
\hline Hotel B2 & Ajudam, pois são ferramentas facilitadoras da operação \\
\hline Hotel C1 & Não respondeu \\
\hline Hotel C2 & Não respondeu \\
\hline Hotel D & $\begin{array}{l}\text { Ajudam mais ou menos, pois acho que teriam que melhorar } \\
\text { mais nosso sistema }\end{array}$ \\
\hline Hotel E & $\begin{array}{l}\text { Ajudam. A tecnologia ajuda a melhorar minha gestão, o que } \\
\text { pode prejudicar é a falta de postura do funcionário frente a } \\
\text { essa tecnologia }\end{array}$ \\
\hline Hotel F & $\begin{array}{l}\text { Atrapalham no momento que os colaboradores esquecem o } \\
\text { trabalho ou param suas atividades para compartilhar notí- } \\
\text { cias fúteis. E ajuda no momento que precisamos nos comu- } \\
\text { nicar }\end{array}$ \\
\hline Hotel G & $\begin{array}{l}\text { Ajudam bastante porque elas facilitam bastante minha comu- } \\
\text { nicação e ajudam no treinamento da minha equipe }\end{array}$ \\
\hline Hotel H & Não respondeu \\
\hline Hotel I & $\begin{array}{l}\text { Ajudam, facilitam o trabalho do dia a dia e o desenvolvi- } \\
\text { mento da equipe }\end{array}$ \\
\hline Hotel J & Não respondeu \\
\hline
\end{tabular}

Fonte: Dados da pesquisa.

\subsection{Você considera a figura do líder como um diferencial para a hotelaria? Em caso afirmativo, justifique.}

Em relação a se o gestor considera a figura do líder como um diferencial para a hotelaria, no Quadro 7 é possível observar que a maioria concordou por diversos motivos: o líder consegue extrair o melhor de cada colaborador; motiva e direciona a equipe de modo geral no fator primordial da hotelaria "bem receber"; a presença dele é extremamente importante para o clima organizacional da empresa; e ele faz toda a diferença diante do cliente. 
Quadro 7: A figura do líder como um diferencial para a hotelaria

\begin{tabular}{|l|l|}
\hline Gestores & Respostas \\
\hline Hotel A & $\begin{array}{l}\text { Sim, pois o líder consegue extrair o melhor de cada cola- } \\
\text { borador, o que permite que o trabalho se torne prazeroso e } \\
\text { flua naturalmente }\end{array}$ \\
\hline Hotel B1 & Sim, um bom líder sempre terá uma ótima equipe \\
\hline Hotel B2 & $\begin{array}{l}\text { Sim, a figura do líder tanto motiva quanto direciona a } \\
\text { equipe de modo geral no fator primordial da hotelaria } \\
\text { "bem receber” }\end{array}$ \\
\hline Hotel C1 & Não respondeu \\
\hline Hotel C2 & Não respondeu \\
\hline Hotel D & $\begin{array}{l}\text { Sim, porque comecei como mensageiro e cresci dentro da } \\
\text { empresa, passando por várias áreas e assim adquirindo } \\
\text { bastante experiência }\end{array}$ \\
\hline Hotel E & $\begin{array}{l}\text { Sim, a hotelaria trabalha com pessoa e fornece serviços a } \\
\text { pessoa. Um líder faz toda a diferença frente a um cliente }\end{array}$ \\
\hline Hotel F & $\begin{array}{l}\text { Sim, não só na hotelaria, mas em qualquer área de atuação, } \\
\text { pois a presença de um líder é extremamente importante } \\
\text { para o clima organizacional da empresa }\end{array}$ \\
\hline Hotel G & $\begin{array}{l}\text { Sim, porque com o líder desempenhando bem sua função e } \\
\text { a sua equipe trará bons resultados para o hotel }\end{array}$ \\
\hline Hotel H & Não respondeu \\
\hline Hotel I & $\begin{array}{l}\text { Sim, um bom líder proporciona uma excelente prestação } \\
\text { de serviço junto com sua equipe }\end{array}$ \\
\hline Hotel J & Não respondeu \\
\hline
\end{tabular}

Fonte: Dados da pesquisa.

A figura do líder é fundamental em qualquer organização, principalmente no setor hoteleiro, pois só ele é capaz de ouvir, aconselhar, motivar seus funcionários, desenvolver as habilidades de cada membro da sua equipe; além disso, sabe o momento certo em que deve ser mais rígido diante de alguma situação e quando deve pedir a opinião da equipe para melhorar a execução das tarefas destinadas a eles. Somente o líder, com suas habilidades e capacidade de administrar tanto as tecnologias quanto os recursos disponíveis, consegue gerenciar os diferentes setores dentro dos hotéis, proporcionando um excelente atendimento aos hóspedes 
e mantendo os empreendimentos hoteleiros competitivos ante os concorrentes e o mercado.

Por isso, as respostas dos gestores se encaixam perfeitamente com relação à importância da figura do líder dentro de um hotel porque o líder é atento às mudanças, inovador, consegue manter o espírito de equipe dentro do ambiente de trabalho, se preocupa com seu funcionário, sabe conduzir e direcionar a equipe diante das tarefas ou qualquer situação que possa acontecer, gerenciar os recursos disponíveis e administrar as tecnologias usadas dentro do hotel.

\subsection{0 quanto que seu estilo de liderança influencia no fun- cionamento da gestão do hotel?}

A partir do Gráfico 11, evidencia-se que 73\% dos gestores afirmaram que influencia muito, ao passo que os outros $27 \%$ correspondem a uma influência regular. Desse modo, o estilo de liderança mais utilizado pelos gestores é a junção dos três (autocrático, liberal e democrático), no qual o líder tanto pode mandar os funcionários cumprirem suas ordens, como os consulta antes de tomar decisões para que sugiram ideias e o trabalho seja realizado da melhor maneira possível. Ele se adequa ao ambiente de trabalho e a sua equipe, a depender de cada situação vivenciada.

Gráfico 11: O quanto seu estilo de liderança influencia o funcionamento da gestão do hotel

O quanto seu estilo de liderança influencia o funcionamento da gestão do hotel



- O quanto seu estilo de liderança influencia no funcionamento da gestão do hotel

Fonte: Dados da pesquisa. 
Na hotelaria, a liderança se faz indispensável em todos os setores, pois apenas o líder com suas habilidades tem capacidade de administrar os recursos disponíveis no hotel e as tecnologias; ao mesmo tempo busca atingir os objetivos da organização e sabe como motivar os funcionários para que os serviços ofertados aos hóspedes sejam bem realizados.

Por isso, a maneira como o gestor lidera com sua equipe exerce muita influência no funcionamento do hotel, visto que é responsabilidade dele utilizar o melhor caminho para executar suas tarefas, mas sem descuidar da equipe, para que o hóspede possa se sentir satisfeito e bem recebido dentro do hotel.

É possível observar no Quadro 12 que em sua maioria os respondentes utilizam os três estilos de liderança (autocrático, liberal e democrático) na sua gestão dentro do setor no qual trabalham, uma vez que o grupo em que está inserido, as situações que podem acontecer e as tarefas que devem ser cumpridas vão determinar o comportamento deles.

Quadro 12: Diferenças e semelhanças nos estilos de liderança

\begin{tabular}{|l|l|}
\hline Gestores & Estilos de liderança \\
\hline Hotel A & Uma mistura dos três estilos \\
\hline Hotel B1 & Uma mistura dos três estilos \\
\hline Hotel B2 & Uma mistura dos três estilos \\
\hline Hotel C1 & Democrático \\
\hline Hotel C2 & Uma mistura dos três estilos \\
\hline Hotel D & Uma mistura dos três estilos \\
\hline Hotel E & Uma mistura dos três estilos \\
\hline Hotel F & Democrático \\
\hline Hotel G & Uma mistura dos três estilos \\
\hline Hotel H & Não respondeu \\
\hline Hotel I & Democrático \\
\hline Hotel J & Autocrático \\
\hline
\end{tabular}

Fonte: Dados da pesquisa. 


\section{CONSIDERAÇõES FINAIS}

O estudo identificou que os estilos de liderança utilizados pelos gestores influenciam o funcionamento dos hotéis localizados na orla de João Pessoa (PB), pois é a maneira como o gestor lidera sua equipe que determina a eficiência na execução das suas tarefas e a manutenção da sustentabilidade do negócio do hotel diante do cenário atual.

De acordo com os achados da pesquisa, os gestores utilizam os três estilos de liderança (autocrático, liberal e democrático) simultaneamente para liderar sua equipe. Quanto à tomada de decisões, afirmaram que concentram as decisões em si mesmos, mas permitem que os funcionários opinem e o ajudem. No comportamento com seus funcionários, é mantido um relacionamento de amizade, no qual se preocupam com o grupo. Já na divisão das tarefas são os gestores que determinam o que cada colaborador deve fazer, o que demonstra que os gestores são flexíveis, isto é, adequam o seu comportamento e sua maneira de liderar à situação, a sua equipe e ao ambiente de trabalho.

Ressalta-se que quando questionados sobre as características que mais se destacam na realização do seu trabalho, os gestores apresentaram as correspondentes a um líder, visto que a preocupação principal era com seus funcionários e, em manter o trabalho de equipe, pois além de administrar os setores no qual trabalham, os líderes precisam cuidar dos colaboradores, gerar confiança e ajudá-los a desenvolverem suas habilidades. Na hotelaria, isso é fundamental, pois o colaborador precisa se sentir bem no ambiente de trabalho para que acolha bem os hóspedes, o que retrata a questão da hospitalidade.

Foi possível observar também que os gestores se consideram líderes justamente por esse trabalho em equipe para alcançar os objetivos do hotel, sua influência dentro do grupo, manter um bom ambiente de trabalho e o apoio que oferecem a cada colaborador. Também consideram a figura do líder como um diferencial para a hotelaria, pois segundo eles um bom líder consegue direcionar sua equipe, proporcionando uma excelente prestação de serviços.

Os gestores afirmaram ainda que o empreendimento hoteleiro no qual trabalham oferece grande abertura em relação à tecnologia, 
a qual auxilia no gerenciamento, treinamento e na comunicação com seus funcionários e clientes, além de tornar o trabalho mais rápido, e o hotel, mais competitivo. A tecnologia não interfere no desenvolvimento da liderança; pelo contrário, contribui para melhor desenvolvimento e permite que o gestor se mantenha atualizado sobre os novos estudos sobre o tema. Apenas a internet e as redes sociais requerem ser monitoradas por eles, uma vez que prejudicam os funcionários na execução de suas tarefas.

Em relação aos desafios apontados pelos gestores no desenvolvimento do seu estilo de liderança, foi possível observar que são frequentes na rotina dos empreendimentos hoteleiros diante do mercado em que estão inseridos. $\mathrm{O}$ mais citado foi manter a equipe motivada, respeitar as diferenças e atender às necessidades de cada membro, para que isso reflita em um bom atendimento dos clientes.

Além disso, o gestor requer estar sempre atualizado para conseguir manter o hotel competitivo anate o contexto externo direto (concorrentes) ou indireto, uma vez que, normalmente, surgem novas práticas de gestão que podem contribuir no seu estilo de liderança e tecnologias que podem ser utilizadas dentro do hotel, proporcionando mais rapidez e efetividade na prestação dos serviços oferecidos aos hóspedes.

Portanto, os gestores são também líderes no seu ambiente de trabalho, visto que sabem administrar os recursos disponíveis dentro do hotel em que trabalham a fim de atingir as metas estipuladas e, ao mesmo tempo, conseguem adequar o estilo de liderança para que saibam o momento certo de elogiar e/ou pedir que sua equipe preste mais atenção ao trabalho. Igualmente, possuem a preocupação de buscar conhecimento para se manterem atualizados diante das novas tecnologias e novas práticas de gestão.

\section{REFERÊNCIAS}

BARRETO, A. A. A transferência de informação, o desenvolvimento tecnológico e a produção de conhecimento. Informare - Cadernos do Programa de Pós-Graduação em Ciência da Informação, v. 1, n. 2, p. 2-10, 1995.

BARRETO, L. G. M.; TANURE, B. Liderança Globalmente Responsável: a percepção dos executivos sobre as práticas existentes nas organizações brasileiras. In: ENCONTRO DA ANPAD, 35., Rio de Janeiro. Anais... Rio de Janeiro: Anpad, 2011. 
BASSOTTO, R. N. O processo de treinamento, desenvolvimento e educação: um estudo junto aos funcionários de recepção de hotéis de rede em Porto Alegre. 153 f. Trabalho de Conclusão de Curso (Bacharelado em Administração) - Universidade Federal do Rio Grande do Sul, Porto Alegre, 2008.

BERGAMINI, C. W. Liderança: A administração do sentido. Revista de Administração de Empresas, v. 34, n. 3, p.102-114, maio/jun. 1994.

BERTHO, M. S. Gestão de Pessoas no Setor Hoteleiro. 38 f. Trabalho de Conclusão de Curso (Pós-Graduação “Lato Sensu") - Universidade Candido Mendes, Rio de Janeiro, 2010.

BLAKE, R. R.; MOUTON, J. S. O Novo Grid Gerencial. São Paulo: Biblioteca Pioneira de Administração e Negócios, 1980.

CANDEIA, D. L. Classificação dos meios de hospedagem: a validade para os empreendimentos. 75 f. Monografia (Especialização em Gestão da Hospitalidade) - Universidade de Brasília, Brasília, 2003.

CASTELLI, G. Excelência em Hotelaria: uma abordagem prática. Rio de Janeiro: Qualitymark, 2000.

CERVO, A. L.; BERVIAN, P. A.; SILVA, R. da. Metodologia científica. 6. ed. São Paulo: Pearson Prentice Hall, 2007.

CHIAVENATO, I. Introdução à teoria geral da administração: uma visão abrangente da moderna administração das organizações. 7. ed. rev. e atual. $8^{\text {a }}$ reimpressão. Rio de Janeiro: Elsevier, 2003.

DALFOVO, M. S.; LANA, R. A.; SILVEIRA, A. Métodos quantitativos e qualitativos: um resgate teórico. Revista Interdisciplinar Científica Aplicada, v. 2, n. 4, p. 1-13, 2008.

DELFINO, I. A. L.; SILVA, A. B; ROHDE, L. R. A produção acadêmica sobre liderança no Brasil: Uma análise bibliométrica dos artigos publicados em eventos e periódicos entre 1995 e 2009. In: ENCONTRO DA ANPAD, 34., Rio de Janeiro, 2010. Anais... Rio de Janeiro: Anpad, 2010.

EBOLI, C.; CAVAZOTTE, F.S.N.; LUCENA, J. O impacto da autenticidade do líder e do foco em resultados sobre o desempenho no trabalho: um estudo com funcionários de um banco privado brasileiro. In: ENCONTRO DA ANPAD, 36., Rio de Janeiro, 2012. Anais... Rio de Janeiro: Anpad, 2012.

ENDLER, E. Liderança x gerenciamento. São Paulo: Abril, 2013.

FROZINO, A. D. Aspectos do desenvolvimento da indústria hoteleira no Brasil. $64 \mathrm{f}$. Monografia (Especialização em MBA - Gerência Empresarial) - Universidade de Taubaté, Taubaté, 2001.

GEHLEN, A. Tecnologia da informação e as vantagens competitivas para a hotelaria. In: SENAC: Um marco na hotelaria: A evolução do setor relatada por grandes líderes. São Paulo, 2012.

GERHARDT, T. E.; SILVEIRA, D. T. Métodos de pesquisa. Porto Alegre: Editora da UFRGS, 2009. 
GUIMARÃES, J. C. Fenômenos acadêmicos: Gestão ou liderança promove maior eficiência em IFES? Um ensaio sob a perspectiva da inteligência empreendedora (IE). In: ENCONTRO DE GESTÃO DE PESSOAS E RELAÇÕES DE TRABALHO, 3., João Pessoa, 20-22 nov. 2011. Anais... João Pessoa: EnGPR/ANPAD, 2011.

HEERDT, M. L. Metodologia científica e da pesquisa. 5. ed. rev. e atual. Palhoça: Unisul Virtual, 2007.

JORDÃO, S. Liderar x Administrar x Gerenciar. Desmistificando conceitos. São Paulo: Ed. Vozes, 2013.

KAUARK, F. S.; MANHÃES, F. C.; MEDEIROS, C. H. Metodologia da pesquisa: guia prático. Itabuna: Via Litterarum, 2010.

LACOMBE, F. J. M. Recursos Humanos: princípios e tendências. São Paulo: Saraiva, 2005.

LATOSKI, A.; MELLO, C.M.; NOGUEIRA, E.E.S. Abordagem fenomenológica sobre liderança: um estudo nas agências de uma instituição financeira localizadas no interior de São Paulo e Minas Gerais. Revista Perspectivas Contemporâneas, v. 9, n. 1, p. 22-42, jan./jun. 2014.

LIMA, G. S.; CARVALHO NETO, A. M. Uma leitura da evolução das teorias sobre liderança à luz da teoria da estruturação de Giddens. In: ENCONTRO DE GESTÃO DE PESSOAS E RELAÇÕES DE TRABALHO, 3., João Pessoa, 20-22 nov. 2011. Anais... João Pessoa: EnGPR/ ANPAD, 2011.

LOBIANCO, M. M. L.; RAMOS, A. S. M. Uso da internet no setor de hotelaria de Recife- PE. RAE-eletrônica, v. 3, n. 2, jul./dez. 2004.

MACEDO, L. César Ritz: O pai da hotelaria moderna. Rio de Janeiro, Saraiva, 2010.

MCGREGOR, D. Leadership and motivation. Cambridge: MIT Press, 1966.

MENEZES, P. D. L.; BALDUINO, B. C.; BALDUINO, J. C.; BRANDÃO, J. M. F. Gestão hoteleira no litoral norte da Paraíba: estrutura e funcionamento. Qualit@s Revista Eletrônica, v. 1 , n. 1 , p. $18,2011$.

PANICE, T. C.; ZANINI, M.; VERRI, R. A. Liderança como ênfase no gerenciamento de pessoas. Jandaia do Sul: CEAD\&CIESTEC - Faculdade de Jandaia do Sul, 2010.

RIBEIRO, H. C. A Hotelaria na Cidade de Porto Alegre: Gestão de Redes e Gestão Familiar. 197 f. Dissertação (Mestrado em Turismo e Hotelaria) - Programa de Pós-Graduação em Turismo, Universidade de Caxias do Sul, Caxias do Sul, 2005.

RICHARDSON, R. J. Pesquisa social: métodos e técnicas. 3. ed. São Paulo: Atlas, 1999.

ROBBINS, S. P. Comportamento Organizacional. 11. ed. São Paulo: Pearson Prentice Hall, 2005.

ROLDAN, V. P. S.; CABRAL, A.C. A.; PESSOA, M. N. M. Estilo de liderança e desempenho criativo em equipes de telejornalismo: um estudo em emissoras de TV cearenses. In: ENCONTRO DA ANPAD, 36., Rio de Janeiro, 2012. Anais... Rio de Janeiro: Anpad, 2012.

SANT'ANNA, A. S.; CAMPOS, M. S.; VAZ, S. L. Liderança: O que pensam executivos brasileiros sobre o tema? In: ENCONTRO DA ANPAD, 34., Rio de Janeiro, 2010. Anais... Rio de Janeiro: Anpad, 2010. 
SANTOS, D. P. Sistemas informatizados de reservas na hotelaria: diagnóstico da utilização nos hotéis localizados no bairro Cerqueira César - São Paulo/SP. 122 f. Trabalho de Conclusão de Curso (Graduação em Turismo) - UNESP, Rosana, 2013.

SANTOS, M. F. A influência da tecnologia de informação na gestão da cadeia de suprimentos: um estudo de caso em uma empresa industrial paraibana. $88 \mathrm{f}$. Trabalho de Conclusão de Curso (Graduação em Administração) - Universidade Estadual da Paraíba, Patos, 2013.

SANTOS, T. L. et al. Os estilos de liderança nas organizações não governamentais da região metropolitana de Belém. In: ENCONTRO DE GESTÃO DE PESSOAS E RELAÇÕES DE TRABALHO, 3., João Pessoa, 20-22 nov. 2011. Anais... João Pessoa: EnGPR/ANPAD, 2011.

SERAFIM, A. Liderança autocrática: características, benefícios, desvantagens. Portal Gestão, 2014.

SILVA, A. C. R. da. Metodologia da pesquisa aplicada à contabilidade: orientações de estudos, projetos, artigos, relatórios, monografias, dissertações, teses. 3. ed. São Paulo: Atlas, 2010.

SILVA, R. O. da. Teorias da Administração. São Paulo: Pearson Prentice Hall, 2008.

TAKAHASHI, A. R. W.; SARSUR, A. M. A Liderança em Organizações Educacionais: Jogando Luz sobre a Administração em "Empresas do Ensino". Teoria e Prática em Administração, v. 2, n. 2, p. 1-26, 2012.

VERASZTO, E. V.; SILVA, D. da.; MIRANDA, N. A.; SIMON, F.O. Tecnologia: buscando uma definição para o conceito. Revista Prisma.com, n. 7,p. 60, 2008.

VIEIRA, J. X. Identificação dos Estilos de Liderança Feminino: um estudo em micro e pequenas empresas em Patos, PB. 23 f. Trabalho de Conclusão de Curso (Graduação em Administração) - Universidade Estadual da Paraíba, 2014.

Recebido em: 5-12-2016

Aprovado em: 24-4-2017

Avaliado pelo sistema double blind review.

Editor: Elmo Tambosi Filho

Disponível em http://mjs.metodista.br/index.php/roc 